\title{
Analysis of Recent Projections of Electric Power Demand
}

D.V. Hudson, Jr.

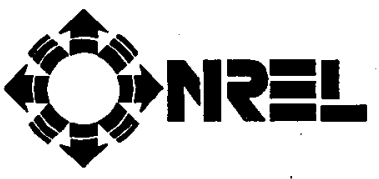

National Renewable Energy Laboratory 1617 Cole Boulevard Golden, Colorado 80401-3393

A national laboratory operated for the U.S. Department of Energy under contract No. DE-AC02-83CH10093

Prepared under Task No. AS815440 


\section{NOTICE}

NOTICE: This report was prepared as an account of work sponsored by an agency of the United States government. Neither the United States government nor any agency thereof, nor any of their employees, makes any warranty, express or implied, or assumes any legal liability or responsibility for the accuracy. completeness, or usefulness of any information, apparatus, product, or process disclosed, or represents that its use would not infringe privately owned rights. Reference herein to any specific commercial product, process, or service by trade name, trademark, manufacturer, or otherwise does not necessarily constitute or imply its endorsement, recommendation, or favoring by the United States government or any agency thereof. The views and opinions of authors expressed herein do not necessarily state or reflect those of the United States government or any agency thereof.

\section{Printed in the United States of America}

Available from:

National Technical Information Service

U.S. Department of Commerce

5285 Port Royal Road

Springfield, VA 22161

Price: Microfiche A01

Printed Copy $\mathrm{AO3}$

Codes are used for pricing all publications. The code is determined by the number of pages in the publication. Information pertaining to the pricing codes can be found in the current issue of the following publications which are generally available in most libraries: Energy Research Abstracts (ERA); Government Reports Announcements and Index (GRA and I); Scientific and Technical Abstract Reports (STAR); and publication NTIS-PR-360 available from NTIS at the above address. 


\section{Preface}

The intended ultimate result of federal investments in renewable energy research and development programs is the use by the private sector of the technologies developed in these programs to provide energy products in the competitive marketplace. Insights about the nature of the present and projected energy markets can help to assure that the technologies being developed are compatible with the competition in these market settings.

The National Renewable Energy Laboratory (NREL) Analytic Studies Program is intended to support the long-range planning of the overall renewable energy program. This is accomplished in part through the development of analytic studies regarding present and projected aspects of competition in energy markets relevant to renewable energy research and development programs. NREL reports on these efforts to the U.S. Deparment of Energy (DOE) and NREL managers to enhance their awareness of competitive and institutional factors that may impact the eventual successful implementation of the renewable energy technologies in the markets.

The initial efforts of the Analytic Studies Program have been focused scoping studies of the fuels and electricity markets. This study was undertaken for the Office of Utility Technologies to review the changes and potential changes in the outlook for electric power demand subsequent to the publication of Review and Analysis of Electricity Supply Market Projections by Blair G. Swezey, SERI/MR-3603322, Solar Energy Research Institute, March 1988. The report reviews the forecasts made by the organizations whose earlier capacity forecasts were reviewed by Swezey-DOE/Energy Information Administration, DOE/Policy Office, DRI/McGraw-Hill, North American Electric Reliability Council, and Gas Research Institute.

Because much of the concern expressed recently has regarded the uncertainty of the demand outlook, a brief review of the supply uncertainty also was conducted to place the uncertainties of the demand outlook in perspective. A detailed analysis of the supply outlook was not made; it is apparent from all outlooks that the electric utility industry is not building much new coal-fired base load capacity. The industry is counting on its ability to build natural gas combustion turbine and/or combined-cycle plants as needed to meet emerging demands over the next decade or two, whether those demands grow at the average forecast of 2 percent per year, the recent average of 3 percent per year, or the lower rate of 1.5 percent per year projected by those who expect conservation and demand side management programs to be more effective than do other forecasters.

The implications on the availability and cost of gas supply and generation facilities may warrant further study well beyond the scope of this analysis. If electricity demand grows more rapidly than now projected, and difficulties are encountered in completing the presently planned coal-fired capacity and modifying existing capacity to meet standards of the Clean Air Act Amendments, the costs of new electricity supply from natural gas may be significantly higher than now projected. The market may be more attractive for renewable energy technologies. This opportunity might continue well after 2000 if the costs of clean coal (or nuclear) capacity are high and/or lead times needed for approval and 
siting of new plants prove to be long. Additional study of the ability of renewable technologies to meet such market challenges may be warranted, taking into account the regional diversity of resource availability and the consequent costs of renewable electricity supply.

Approved for the

NATIONAL RENEWABLE ENERGY LABORATORY

Thomes D. Bast

Thomas D. Bath, Director Analytic Studies Division

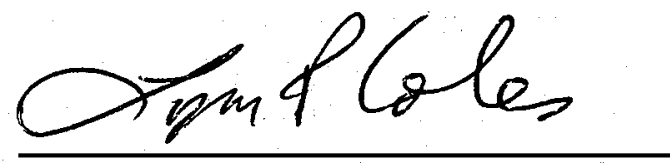

Lynn R. Coles, Manager Analysis and Assessment Projects 


\section{Summary}

The outlook for the growth of electric power demand has changed radically over the past two decades. No longer is demand for electricity projected to expand by 5 to 7 percent, or more, per year. No longer is demand expected to increase at rates exceeding that of the growth of the economy. Most long-term projections of electric power demand incorporate growth rates of 2 percent per year or less. The differences among forecasts are small in contrast to those of the past. It would appear that there is a consensus that conservation has set in-but has it?

Both recent trends in actual demand and current forecasts indicate that electric power is being used more sparingly than in the past. This has occurred despite the development and expansion of markets for new electric and electronic appliances for the home, office, and industry and the substitution of electric controls and power for those previously used. Efficiencies of electricity use have improved. New electric appliances and industrial equipment are more efficient than their predecessors. New programs and systems are being utilized to use electric power resources more efficiently. The full potential savings, however, are not being realized because consumers and industry have not replaced or modemized all their inefficient equipment and facilities, and they continue to buy appliances and construct buildings of less than optimal performance. The principal forecasts do not project that the maximum economic potential savings will occur. The 1991/1992 National Energy Strategy Scenario assumes the implementation of many efficiency and conservation programs; its projections of electricity demand were lower than the principal forecasts but are still well above the potential levels claimed feasible by several groups that advocate conservation. Since the passage of the Energy Policy Act, some forecasts of future electricity demand have been reduced, notably the Energy Information Administration's 1993 Annual Energy Outlook. Nonetheless, greater conservation could be achieved than is projected by the EIA.

What has changed, and what has not?

- The price of electricity in constant dollars is lower today than it was 30 years ago. The levels are significantly lower for residential and commercial consumers, whereas industrial users, on average, are paying more. Because income per capita and appliance efficiency are up, the cost of electricity per kilowatt-hour is a lesser factor in consumer decision making today than it was 30 years ago. The impact of lower prices is partially offset in instances in which demandside management (DSM), appliance standards and labeling, building standards, and other programs have been devised and implemented to better inform consumers regarding costs and thereby affect their decisions, often with the aid of financial incentives. The outlook suggests that there is likely to be little, if any, increase in the real cost of electricity in the next two decades, particularly if the projected higher oil and natural gas prices fail to fully materialize and if inflation remains at today's moderate rates and interest rates, therefore, respond in a similar manner. (The interest rates assumed applicable in ratemaking in the electricity price projections may prove to be high and the price/competitiveness of electricity understated.) Thus the improving "competitiveness" of electricity versus consumers' other choices portends an increasing demand for electricity. If the regulated price of electricity, usually based on average historical cost, does not reflect the full cost of capacity expansion (both generation and transmission and distribution), then the consumer is receiving a distorted signal that encourages increased use of electricity versus other energy and other goods and services. It is not clear whether most forecasters are taking the full range of price effects into account in their projections. 
- The economy is projected to grow at slower rates in the future than in the past. The loss of international competitiveness, the shift by consumers from saving to increased consumption, the reduction of tax incentives for investment, and the slower growth of the work force have contributed to the projected slowdown. The current recession has slowed the growth of electricity demand. The economics staff of the Edison Electric Institute estimates a 0.7 shortterm elasticity of electricity demand to gross national product (GNP) (a 1 percent year-to-year change in GNP is estimated to induce a 0.7 percent change in electricity sales), other factors being equal. The principal forecasts reviewed below attribute a 0.65 to 0.9 overall elasticity of electricity demand to growth of GNP.

- The residential and commercial sectors, the fastest growing sectors in the 1950s and 1960s, are expected to register much slower growth in the coming decades, partly as the result of demographics-a slowing in the rate of family formation and housing needs. In addition, changes in the financial markets and tax regulations have made housing and commercial property development and ownership relatively more costly than other choices for investment and consumption than in the past, resulting in smaller housing units (and more doubling up of families) and less use of extensive commercial space.

- Changes in regulation of the electric utility industry that have profoundly changed the competitive structure of the market have opened many new options to electricity consumers, particularly in the industrial sector. Cogeneration of power, with the utilities providing backup power at reasonable costs, has become feasible and has been rapidly implemented by many of the larger establishments when the economics are attractive. Greater use of time-ofday/seasonal demand/commodity rates have better identified the causal factors of electric service costs and thus allowed industrial and larger commercial consumers to reduce their power demands and costs more effectively than feasible with flat kilowatt-hour rates. Replacement of bulk sales to apartment complexes with individual meters dramatically reduced electricity use and peak demands by giving consumers more cost-oriented price signals. Providing utilities with financial incentives, rather than disincentives, to encourage conservation and DSM programs may prove to have greater impact than now envisioned.

- From 1977 to 1987, the utilities responding to the North American Electric Reliability Council (NERC) surveys of demand, supply, capacity, and related plans, in aggregate lowered their forecasts of future demand each year (Figure S-1). Since 1987, however, as electricity demand has exceeded the forecast by small amounts (except in 1991 and 1992), the utilities have (cautiously) increased their forecasts each year in response. The increases, moreover, have been small in each instance; the forecasts were increased by little more than the amount by which the latest historical year's actual demand exceeded the projection made that year. (No significant reductions were made in the 1991 and 1992 longer term projections.) Many utilities have incentives to minimize projected demand and the concomitant capacity needs, given the uncertain regulatory environment and their desire to avoid commitments for unneeded capacity, particularly long-lead-time base load plants. A modest underforecast of demand would reduce pressures from the commissions and others to commit for new capacity, especially long-lead-time base load units, and thereby retain greater flexibility of choice of types of units and ownership alternatives-utility-owned, independent power producers, cogenerators, joint ownership, etc.

- DSM programs are being promoted and implemented with the "promise" of reduction of peak loads and generation capacity requirements. Presumably a significant proportion of the slowdown in projected demand growth, in contrast to trends in the 1950s and 1960s, is related to the DSM programs, appliance and building standards, and improvements in technology. 


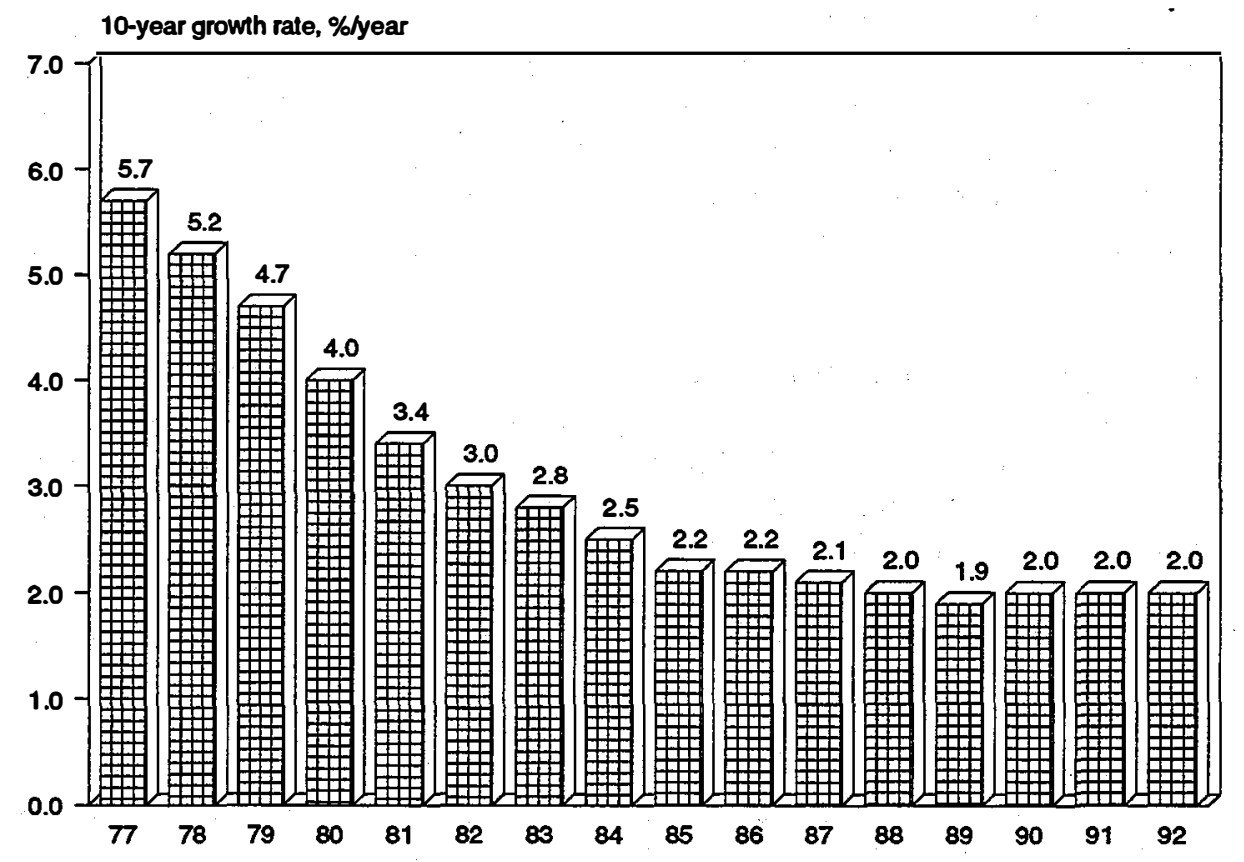

Catman and Tabert, 1989, NERC 1989-92

Figure S-1. NERC demand projections consistently declined over the decade 1977-1987.

Proof of the effectiveness of DSM programs, the Energy Policy Act, and other government policy actions assumed in the forecasts remains to be demonstrated, introducing additional uncertainty of demand. (The Clinton administration's conservation-oriented energy policy, yet to be clearly enunciated, is not directly reflected in the forecasts reviewed herein.) Similarly, many utilities have negotiated interruptible supply contracts with industrial and other customers. Some such contracts apparently have been accepted by customers on the basis that interruption would be unlikely and the contracts were effectively cost-free discounts.

If interruptions do occur, particularly if repetitive, many customers may discover that the costs of interruption greatly exceed the benefits of lower rates and then attempt to retum to regular supply contracts.

- Supply, which in the past was assumed to be certain, has become uncertain, possibly to a greater degree than demand. Thus estimates of the variability of demand are not the only or even the largest indicators of possible supply problems. The uncertainty of supply from cogenerators and independent power producers has been a significant concern, both with respect to the probability that many of the certificated projects will not be built, and with respect to the ability and willingness of the operators of established projects to deliver 
electricity when it is needed. ${ }^{1}$ More recently, however, a growing proportion of the nonutility power projects involve participants that are related to utilities outside the immediate service area(s) involved, ameliorating many of the concerns regarding uncertainty. The 1990 amendments to the Clean Air Act have created additional uncertainty about the availability of both existing and planned capacity; the modifications of existing plants and/or their fuels required for compliance may result in some plants being retired and others being down-rated. All the regulations have not been promulgated. Thus an analysis of the variability of demand will provide only a portion of the necessary assessment of the adequacy of planned supply for the future.

- The utilities project electric power demand to grow at 2 percent per year over the next decade. The EIA projects a lower growth rate, 1.65 percent, for the next two decades. The 1991/1992 National Energy Strategy (NES) Scenario projects electricity demand to grow at a 2 percent per year rate for the next two decades, despite assumptions of very substantial but unspecified conservation in the industrial sector and assumptions of no further penetration of air conditioning in the residential and commercial markets. If the high rate of economic growth projected in the NES is not fully realized, as the other forecasters suggest is more likely, some of the optimism in other sectors may be offset.

Improvements are being made continually in the efficiency of appliances and electricity-powered equipment; this is no change from the past, both before and after the energy crises of the 1970s. Similarly, improvements are being made in building technologies that reduce electricity and other fuel requirements. New industrial process technologies are being developed that reduce electric power needs. All these conservation actions reduce the consumer's cost of the equipment that uses electricity, and increase the demand for that equipment and thus for electricity services at the same time. For example, the Gas Research Institute forecast of electricity demand includes very large increases in appliance and equipment market saturation, while also projecting substantial improvements in efficiencies in all sectors; part of the increased saturation would be the result of consumers reacting to the cost savings provided by the improved efficiency. The improvements in the technologies are more certain than are the projections of their market penetration. If consumers continue to buy equipment using older, less efficient technologies, whether due to original cost, lack of information, or complexity of changeover, the result may be a significantly faster growth of electric power demand than now generally forecast. If a major new use, or particularly a new need, for electricity were to evolve, the outlook might change materially.

The limited detail and discussion provided with most of the forecasts do not give sufficient information about the underlying GDP/GNP assumptions, sectoral demand assumptions, competing energy prices, or forecasting mechanics to provide a reader with much comfort in choosing one outlook over any other. Several of the current major forecasts are summarized in Table S-1. Forecasts of growth of demand range from 1.5 to 2.6 percent per year. The higher forecast, the NES Base Case, assumes higher economic growth and moderate conservation efforts (in contrast to the NES Strategy Scenario) whereas the lowest forecast, DRI/McGraw-Hill's, assumes both lower economic

\footnotetext{
1 IPPs and, in particular, cogenerators may be less reliable as the result of potential financial problems, the need for an outlet for steam or process heat if the related manufacturing facility closes, or other factors, such as storms. For example, Houston Lighting \& Power, one of the larger users of IPP and cogenerated energy, contends that many of its independent power producers/qualifying facility (IPP/QF) suppliers advised them that they might invoke force majeure clauses and shut down when a hurricane recently approached the South Texas coast, precisely the time at which dispersed generating resources might have their greatest value. Some of these risks may be ameliorated by contractual provisions. However, the entry of firms, such as Dominion Energy, in the IPP industry may change its character substantially, bringing greater resources, operating experience, and thus reliability into the IPP sector (Leasburg 1989).
} 
Table S-1. Comparison of Projections of U.S. Electric Power Demand

\begin{tabular}{|c|c|c|c|c|}
\hline \multirow[b]{2}{*}{ Forecast } & \multicolumn{2}{|c|}{$\begin{array}{c}\text { Annual } \\
\text { Demand } \\
\text { (billion kWh) }\end{array}$} & $\begin{array}{c}\text { Annual Rate (\%) } \\
\text { of Increase in } \\
\text { Consumption } \\
(\mathrm{kWh})\end{array}$ & $\begin{array}{l}\text { Ratio of Growth of } \\
\text { Electricity } \\
\text { Consumption (kWh) } \\
\text { to GNP Growth }\end{array}$ \\
\hline & 1990 & 2010 & & \\
\hline EIA 1993 Annual Energy Outlook & 2824 & 3912 & 1.64 & 0.81 \\
\hline $\begin{array}{l}\text { DRI Fall-Winter 1992-1993 } \\
\text { Energy Outlook }^{\mathrm{b}}\end{array}$ & 2667 & 3815 & 1.81 & 0.89 \\
\hline EEI 1992 Electricity Futures ${ }^{c}$ & $2876^{\mathrm{d}}$ & 3940 & 1.76 & 0.84 \\
\hline GRI 1992 Energy Outlook ${ }^{e}$ & 2667 & 3542 & 1.43 & 0.72 \\
\hline NERC 1992 Demand Outlook ${ }^{f}$ & 2887 & 3514 & 1.98 & na \\
\hline 1991/1992 NES Strategy Scenariog & 2700 & 4012 & 2.00 & 0.67 \\
\hline $\begin{array}{l}\text { 1991/1992 NES Current Policy } \\
\text { Base Case }\end{array}$ & 2700 & 4494 & 2.58 & 0.88 \\
\hline
\end{tabular}

a. EIA (Energy Information Administration, U.S. Department of Energy).

b. DRI/McGraw-Hill.

c. EEI (Edison Electric Institute).

d. 1992 (the growth rates are from 1992 to 2010).

e. GRI (Gas Research Institute).

f. NERC projections are from 1990 to 2000 and are based on electricity produced for load.

g. The NES projections are based on significantly higher forecasts of economic growth than the other forecasts.

growth and more effective conservation programs. Nonetheless, the range of variation is small, and the average of about 2.0 percent contrasts greatly with the outlooks of only 14 years ago, as shown in Figure S-1, as reported by the Electric Power Research Institute (EPRI) (Oaman and Talbert 1989). -The assumption by some forecasters, however, that their current forecasts are relatively accurate is very questionable. NERC, for example, asserts that there is an 80 percent probability that peak demand growth between 1991 and 2001 will average between 0.7 and 2.9 percent per year, the 50 percent probability case being 1.8 percent per year (slightly less than NERC's forecast of 2.0 percent growth in kilowatt-hours generated for load) (North American Electric Reliability Council 1992, 8-9). The dramatic changes in NERC's projections during the recent decade covered by the figure do not inspire confidence in anyone's ability to accurately forecast demand. If the \pm 14 percent range of variation in demand by 2001 were also applicable to kilowatt-hours supplied, the 80 percent confidence range of demands in 2000 would be from about 3090 billion kWh to 3930 billion kWh; if demand were to grow at the 4.0 percent rate NERC projected a decade ago, demand in 2000 would reach 4270 billion $\mathrm{kWh}$, or well outside the claimed 80 percent confidence range.

Although probably outside the time frames of the forecasts, other than the NES projections, the forecasts are silent about the potential impact of the general use of battery-powered electric vehicles. A modest rate of penetration, 10 to 20 percent, might be feasible in most regions with the utilities planned mix of base and intermediate load capacity. A substantially greater penetration, regionally or 
nationally, could have a significant effect. Not only would the impact on utility sales and demand be great, but the impact might be profound on the structure of supply. The industry's capacity would not only have to include a larger proportion of base load technologies but also a higher reserve margin. Cheap, off-peak power may not be widely available to recharge batteries if, by 2020 or 2030, the bulk of autos and light trucks in use prove to be battery-powered electric vehicles. ${ }^{2}$

Demand uncertainty is great. Supply uncertainty may be even greater, however. Unlike the past, when planned supplies, virtually all from utility sources, could be counted on, today supply availability is a major concern. In the past, demand uncertainty was the greatest unknown, and capacity construction plans were devised to permit adjustment, upward or downward, to meet demand as it materialized. In a high-growth environment, overbuilding of capacity, such as during a recession, resulted in only temporary overcapacity if a utility was not able to slow down construction. In today's low-growth environment, many years might be required for a small- or medium-sized utility's load to expand to fully utilize a large plant addition occasioned by an overly optimistic forecast. Regulatory commissions have disallowed costs of additions deemed unwarranted at the time of being placed in service. Caution is being exercised in new plant commitments, not only because of the uncertainties of demand, but also because of the uncertainties of supply.

New uncertainties are prominent today: (1) DSM programs, which could be characterized as elements of demand instead of supply, are being implemented and counted on to reduce peak demand. Their efficacy is yet to be fully demonstrated; they may be more or less effective than assumed in capacity plans. (2) Nonutility generators are projected to supply a very large portion of new capacity needs. Many projects that were licensed or approved in the past have not materialized. Those that are completed and become operational may be less responsive to the utilities' needs at peak load periods than has been assumed (some may even fail). (3) The major portion of the projected utility-owned capacity needed to meet expansion needs by 2010 does not have regulatory approvals, and the site approval process is also to be started in many cases. (4) The Clean Air Act Amendments of 1990 imposes substantial burdens on the utilities; much of this burden is yet to be defined. Many plants may be closed, others down-rated, and planned new plants and sites may be abandoned or canceled. (5) Much of the anticipated utility capacity to be added is expected to be fueled by natural gas. The availability of enough gas at the sites and at attractive prices is not certain. Most projections of gas prices predict sharp increases around 2000 in response to supply pressures. ${ }^{3}$ Should electricity demand growth be greater than that forecast, the natural gas supply and price situation might be tighter than projected, particularly if environmental regulations also force greater use of natural gas in existing coal and oil plants than is now projected.

Fortunately, the electric utility industry is usually given adequate waming of unforecasted capacity needs by the emergence of demand (or supply) trends early enough to permit an orderly and economic

2 Although a substantial number of electric vehicles could be recharged using existing or planned generation capacity, the type of capacity would change if the bulk of vehicles were electric powered. A greater proportion of capacity would be base load and intermediate load units because prolonged operation of peaking turbines would not be economical. Greater reserve margins would be required for such units and for the scheduling of routine maintenance. Off-peak generation capacity also would have to be retained to refill pumped storage. (Hydro projects that have limited daily water flow might be able to provide less-than-full capacity in supplying battery recharging demand.) (This potential is alluded to in Holt 1993, 15.)

3 The EIA 1993 Annual Energy Outlook projects electric utility gas costs to increase by one-third between 1990 and 2000 and nearly double by 2010 . The Gas Research Institute (GRI) projects a 50 percent increase by 2010 . (U.S. Department of Energy 1993, 84) (Gas Research Institute 1993, 14). 
response by supply planners. In view of the reluctance today of utilities to build, and of regulators to approve, large long-lead-time base load plants, any supply gap that does materialize will tend to be supplied by short-lead-time, modular plants, pending a change in the outlook for the approval and construction of new "clean" coal or nuclear capacity. In the 1995-2010 time period, such plants are likely to be gas fired, unless renewable generation technologies have progressed to the competitive stage.

The implications of substantial reliance on natural gas (possibly supplemented temporarily by distillate or treated heavy fuel oil) combined cycle and combustion turbine plants need to be evaluated. If electricity demand growth exceeds forecasts by 1 percent per year, ${ }^{4}$ demand for natural gas could be 3 trillion cubic feet $(\mathrm{Tcf})^{5}$ ( 3 quads) higher in 2000 than projected, and demand for natural gas, coal, or nuclear capacity could be the equivalent of $8 \mathrm{Tcf}$ ( 8 quads) of gas demand higher by 2010 . (Additional pressures would be placed on the supply system if battery-powered electric vehicles should become a significant part of the transportation system by 2010.) The strain on gas supplies, from exploration to production, pipeline movement, and delivery would be substantial, placing additional upward pressures on prices.

If electricity demand continues to expand at such rates, construction plans for additional coal capacity are likely to have to be initiated before 2000 . The competitive environment for renewable energy technologies would be more favorable, particularly considering the environmental advantages and the modularity of many of the renewable technologies.

The demand outlook suggests that there is considerably greater potential for demand to exceed the forecasts than for the opposite. No new uses appear to be considered in any of the outlooks. Consumers may continue to buy lower-first-cost, less-efficient appliances and buildings if there is no compelling incentive to do otherwise. The Energy Policy Act of 1992 mandates some improvements, particularly in industrial applications for electric motors and for lighting, and promotes adoption of more effective building and appliance standards. However, in the absence of stronger programs to promote and encourage conservation and the adoption of more stringent appliance and building standards, or without another energy crisis that focuses consumer attention on reliability of supply and vulnerability to dramatic increases in costs, such behavior by consumers and builders/suppliers is more likely than not.

\footnotetext{
${ }^{4}$ Or an equivalent combination of greater total power demand and shortfalls in coal plant availability, possibly due to greater than anticipated down-rating of capacity and closures in lieu of conversion to low sulfur coal or installation of Flue Gas Desulfurization System (FGDS) facilities. Cofiring natural gas in coal units would also increase gas demand.

51 cubic foot $=2.8631685 \times 10^{-2}$ cubic meter.
} 


\section{Table of Contents}

$\underline{\text { Page }}$

Introduction $\ldots \ldots \ldots \ldots \ldots \ldots \ldots \ldots \ldots \ldots \ldots \ldots \ldots \ldots \ldots \ldots \ldots \ldots$

Recent Developments in Electricity Demand $\ldots \ldots \ldots \ldots \ldots \ldots \ldots \ldots \ldots \ldots \ldots \ldots$

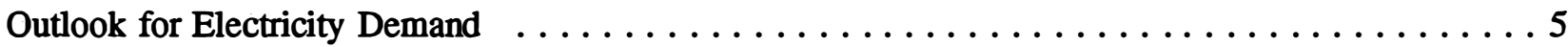

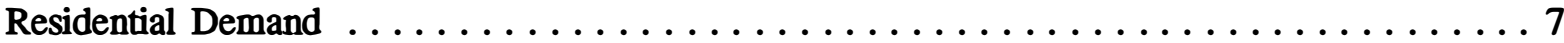

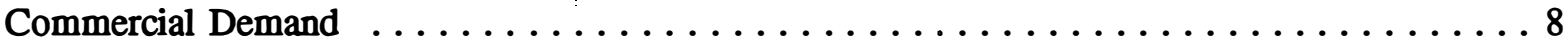

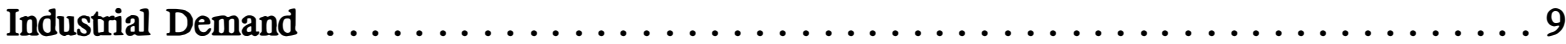

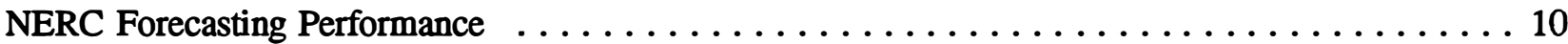

Evolution of New Markets $\ldots \ldots \ldots \ldots \ldots \ldots \ldots \ldots \ldots \ldots \ldots \ldots \ldots \ldots \ldots \ldots$

Emergence of Cogeneration and Self-Generation $\ldots \ldots \ldots \ldots \ldots \ldots \ldots \ldots \ldots \ldots \ldots$

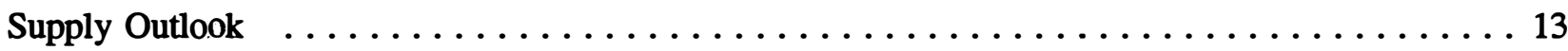

New Capacity under Construction $\ldots \ldots \ldots \ldots \ldots \ldots \ldots \ldots \ldots \ldots \ldots \ldots \ldots \ldots \ldots$

Impact of Efforts to Improve Load Factors $\ldots \ldots \ldots \ldots \ldots \ldots \ldots \ldots \ldots \ldots \ldots \ldots \ldots$

Impact of Uncertainties of Demand and Supply $\ldots \ldots \ldots \ldots \ldots \ldots \ldots \ldots \ldots \ldots \ldots \ldots \ldots$

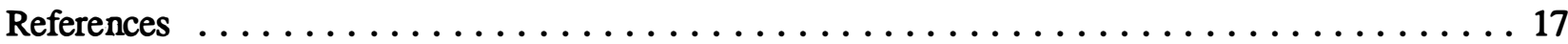

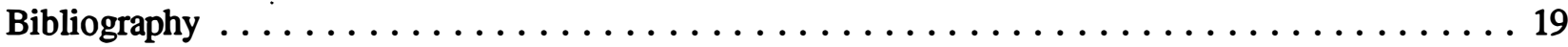




\section{List of Figures}

Page

S-1. NERC demand projections have consistently declined over the past decade.

1. NERC demand projections have consistently declined

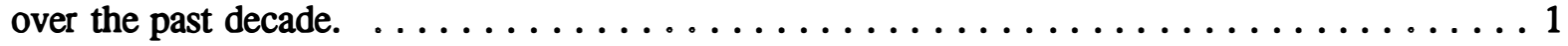

2. Trends in the real price of electricity by demand sector $\ldots \ldots \ldots \ldots \ldots \ldots \ldots$ 


\section{List of Tables}

$\underline{\text { Page }}$

S-1. Comparison of Projections of U.S. Electric Power Demand $\ldots \ldots \ldots \ldots \ldots \ldots \ldots$

1. Rates of Growth in Electric Power Demand

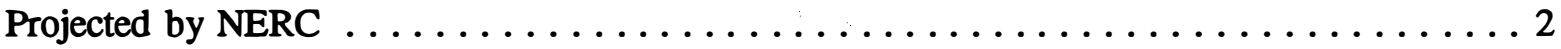

2. Comparison of Projections of U.S. Electric Power Demand $\ldots \ldots \ldots \ldots \ldots \ldots \ldots \ldots$

3. Projected Growth Rates in Demand for 1990 to $2000 \ldots \ldots \ldots \ldots \ldots \ldots \ldots$

4. Actual and Forecast: Electricity for Load and

Peak Demands ............................. 4

5. Analysis of Variations in U.S. Electricity Sales on a

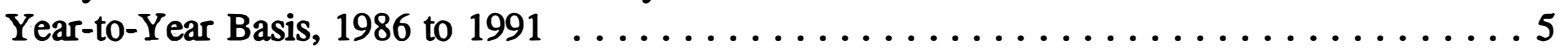

6. Historical Growth of Electricity Sales by Sector $\ldots \ldots \ldots \ldots \ldots \ldots \ldots \ldots \ldots$

7. Forecast Growth Rates (\%) of Electricity Demand by Sector, 1990 to 2010 . . . . . . . . . . . . . . . . . . . . . . . . . . . . . 9

8. Cogeneration and Self-Generation Supply for Utility Sales and Producers' Own Use (billion kWh) 


\section{Introduction}

This study was undertaken for the Office of Utility Technologies to review the changes and potential changes in the outlook for electric power demand subsequent to the publication of Review and Analysis of Electricity Supply Market Projections by Blair G. Swezey, SERI/MR-360-3322, Solar Energy Research Institute (SERI), March 1988. In that report, it was noted that the projected rates of growth of both peak demand and electricity sales were being marked down in each succeeding forecast. An Electric Power Research Institute (EPRI) study (Oatman and Talbert 1989) the following year presented a similar portrayal of the trend in forecasts, using the annual North American Electric Reliability Council (NERC) projections as an illustration, as shown in Figure 1.

Since the SERI and EPRI studies were conducted, the demand for electric power has tended to exceed forecasts, due in part to extreme weather conditions, giving rise to concerns that the outlook may now be dramatically different than it appeared a few years ago. In contrast to the trends shown in Figure 1, the NERC projections (Table 1) of the rate of growth in electricity supplied for load have shown remarkable stability from 1987 to 1991, despite the fact that near-term demand has exceeded the prior year's forecast; growth averaged 3 percent between 1986 and 1991. The 1991-1992 recession reduced demand growth; in addition, both winter and summer weather were milder in 1992, in contrast to the severe weather patterns of most prior recent years.

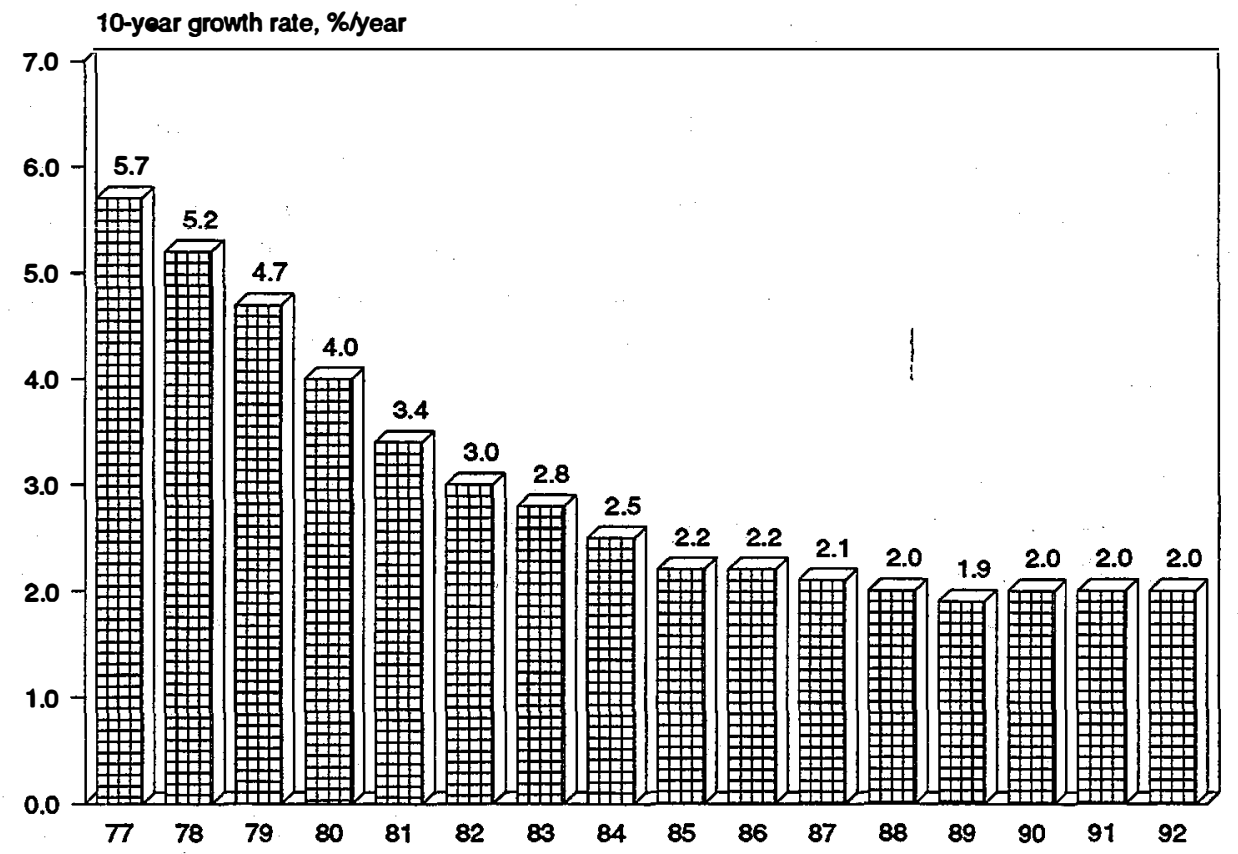

Oatman and Tabert, 1989, NERC 1989-92

Figure 1. NERC demand projections consistently declined over the decade 1977-1987. 
Table 1. Rates of Growth in Electric Power Demand Projected by NERC

\begin{tabular}{|c|c|}
\hline NERC Projection & $\begin{array}{c}\text { Annual Rate of Growth (\%) } \\
\text { 10-Year Outlook }\end{array}$ \\
\hline 1987 & 2.10 \\
1988 & 1.96 \\
1989 & 1.93 \\
1990 & 2.01 \\
1991 & 1.99 \\
1992 & 1.99 \\
\hline
\end{tabular}

Source: NERC, Electricity Supply \& Demand, 1987-1992 reports.

Moreover, the uncertainties in the demand outlook, heretofore considered the principal source of uncertainty, may now be overshadowed by uncertainties in the supply sector. This study is concerned primarily with the changes, potential changes, and range of uncertainty in the demand outlook. It will also address some of the supply issues in more general terms in order to place them in better perspective with the demand issues. The opportunities (or needs) for attractive applications of conservation programs appear great, as do the opportunities for renewable energy technologies. The opportunities for both, however, will be fashioned in large part by the successes achieved in the development of the conservation programs and the progress achieved in the research, development, and demonstration (RD\&D) programs of renewable technologies.

The relative stability of recent projections is not confined to those of the utilities contributing to the NERC report. The other principal forecasters are also projecting electricity demand to grow at about a 2 percent annual rate, as shown in Table 2. (The growth rates projected for 1990 to 2000 are shown in Table 3, permitting a more relevant comparison of other forecasts to NERC's, which are limited to the 10-year period.) Meanwhile, electric power demand on the utilities (electricity for load) grew at a 2.9 percent rate from 1985 to 1990 . The current recession may have slowed the growth in 1991 and 1992, but it may rebound in 1993.

An interesting feature of the comparison of the forecasts is that the utilities' projections of demand are among the highest. As a consequence of the changed regulatory environment in which the utilities are at risk for (over)investing to meet demand that does not materialize, one might expect the utilities to have lower than average forecasts of demand growth. In addition, a conservative sales forecast would tend to result in higher rates being allowed for the test year and the immediate future. Although refunds are likely to be ordered by commissions if rates prove to be too high, no relief is available to the utilities if rates are set too low. (Exceptions might be found among those utilities currently having excess capacity that they wish to juslify with projections of rapidly growing demand in the near term.) However, the NERC projection of demand is comparable to the forecasts made by others, with the exception of the National Energy Strategy (NES) projections, which are predicated on significantly higher growth rates of gross national product (GNP) than are the other outlooks.

\section{Recent Developments in Electricity Demand}

Electricity demand has exceeded expectations during many of the past seven years. Two major factors contributed to the greater than anticipated growth-weather and expansion of the economy. The first factor, weather, contributed more to the expansion of peak demand $(\mathrm{kW})$ than to total annual sales of electricity (kWh). The second, greater-than-projected economic growth was the primary influence in 
Table 2. Comparison of Projections of U.S. Electric Power Demand

\begin{tabular}{|c|c|c|c|c|}
\hline \multirow[b]{2}{*}{ Forecast } & \multicolumn{2}{|c|}{$\begin{array}{c}\text { Annual } \\
\text { Demand } \\
\text { (billion kWh) }\end{array}$} & \multirow[t]{2}{*}{$\begin{array}{c}\text { Annual Rate (\%) } \\
\text { of Increase in } \\
\text { Consumption } \\
(\mathrm{kWh})\end{array}$} & \multirow[t]{2}{*}{$\begin{array}{l}\text { Ratio of Growth } \\
\text { of Electricity } \\
\text { Consumption } \\
\text { (kWh) to } \\
\text { GNP Growth }\end{array}$} \\
\hline & 1990 & 2010 & & \\
\hline EIA 1993 Annual Energy Outlook ${ }^{a}$ & 2824 & 3912 & 1.64 & 0.81 \\
\hline $\begin{array}{l}\text { DRI Fall-Winter 1992-1993 Energy } \\
\text { Outlook }^{\mathrm{b}}\end{array}$ & 2667 & 3815 & 1.81 & 0.89 \\
\hline EEI 1992 Electricity Futures ${ }^{c}$ & $2876^{\mathrm{d}}$ & 3940 & 1.76 & 0.84 \\
\hline GRI 1992 Energy Outlook ${ }^{\mathbf{e}}$ & 2667 & 3542 & 1.43 & 0.72 \\
\hline NERC 1992 Demand Outlook ${ }^{f}$ & 2887 & 3514 & 1.98 & na \\
\hline 1991/1992 NES Strategy Scenariog & 2700 & 4012 & 2.00 & 0.67 \\
\hline $\begin{array}{l}\text { 1991/1992 NES Current Policy Base } \\
\text { Case }^{\mathbb{B}}\end{array}$ & 2700 & 4494 & 2.58 & 0.88 \\
\hline
\end{tabular}

a. EIA (Energy Information Administration, U.S. Department of Energy).

b. DRI/McGraw-Hill.

c. EEI (Edison Electric Institute).

d. 1992 (the growth rates are from 1992 to 2010).

e. GRI (Gas Research Institute).

f. NERC projections are from 1990 to 2000 and are based on electricity produced for load.

g. The NES projections are based on significantly higher forecasts of economic growth than the other forecasts.

Table 3. Projected Growth Rates in Demand for 1990 to 2000

\begin{tabular}{||l|c||}
\hline \multicolumn{1}{|c|}{ Forecast } & $\begin{array}{c}\text { Percent } \\
\text { per Year }\end{array}$ \\
\hline \hline EIA 1993 Annual Energy Outlook & 1.83 \\
DRI Fall-Winter 1992-1993 Energy Outlook & 1.86 \\
EEI 1992 Electricity Futures & $1.89^{\mathrm{a}}$ \\
GRI 1993 Energy Outlook & 1.50 \\
NERC 1992 Electricity Supply \& Demand Outlook & 1.99 \\
NES Strategy Scenario & 2.55 \\
NES Current Policy Base Case & 2.91 \\
\hline
\end{tabular}

a. $1992-2000$ 
the rate of expansion of kilowatt-hour sales. Table 4 shows for the United States the actual electricity supplied for load and noncoincident peak demand for recent years compared with NERC forecasts for each of those years made one year earlier (e.g., the actual data for 1987 versus the forecasts made in the 1986 NERC report).

The Strategic Planning Deparment of the Edison Electric Institute (EEI) analyzed the year-to-year variations in electric power sales of the utilities (Table 5) in 1992 (a similar analysis was not conducted in early 1993). EEI estimated the effects on total utility sales of weather, income (GNP/gross domestic product [GDP]), relative prices of electricity, and other factors. (The sales data were adjusted to correct for the 15-day typical average lag in billing, which otherwise often distorts the analysis of the impact of the highly variable patterns of December weather. ${ }^{1}$ )

EEI estimates the income effects (GNP/GDP) to have an elasticity of about 0.7 . The weather effects have had a variable impact, largely as expected. The impact of the 1991-1992 recession is apparent in the analysis of the 1991 data. The price effects, often ignored by forecasters, have been great, particularly in the earlier years. The real price of electricity has been falling (as have fossil fuel prices); consequently EEI's analysis attributes a substantial part of the increase in demand to the price effects. In 1992, EEI estimated that the 0.5 percent increase in sales was the result of a 1.9 percent increase due to economic growth and a 0.6 percent price elasticity effect offset largely by a negative 2.0 percent weather effect (primarily a cooler than normal summer). In the coming decade, if oil and natural gas prices rise as sharply as the Energy Information Administration (EIA) (and most other) forecasts suggest, and electricity prices continue to be constrained by cost-of-service regulation, ${ }^{2}$ demand for electricity service may be stronger than is now being projected.

The effects of extreme weather during the past five years have been greater on noncoincident peak demand than on sales (or generation). However, all regions have not had simultaneous peaks, and substantial analysis of regional capacity availability would be required before one could conclude that the strain on generation resources was measured reasonably by the sum of the noncoincident peaks.

Table 4. Actual and Forecast: Electricity for Load and Peak Demands

\begin{tabular}{||c||c|c|c||c|c|c||}
\hline \multicolumn{1}{||c|}{} & \multicolumn{3}{c||}{$\begin{array}{c}\text { Electricity Supplied for Load } \\
\text { (billion kWh) }\end{array}$} & \multicolumn{3}{c||}{$\begin{array}{c}\text { Noncoincident Peak Demand } \\
\text { (gigawatts) }\end{array}$} \\
\cline { 2 - 8 } & Actual & $\begin{array}{c}\text { Forecast } \\
\text { One Year } \\
\text { Earlier }\end{array}$ & $\begin{array}{c}\text { Percent } \\
\text { Variance }\end{array}$ & Actual & $\begin{array}{c}\text { Forecast } \\
\text { One Year } \\
\text { Earlier }\end{array}$ & $\begin{array}{c}\text { Percent } \\
\text { Variance }\end{array}$ \\
\hline \hline 1987 & 2644 & 2589 & 2.1 & 496.2 & 484.5 & 2.4 \\
\hline 1988 & 2769 & 2690 & 3.0 & 529.5 & 500.3 & 5.8 \\
\hline 1989 & 2850 & 2802 & 1.7 & 523.4 & 521.9 & 0.3 \\
\hline 1990 & 2887 & 2890 & -0.1 & 545.5 & 539.3 & 1.2 \\
\hline 1991 & 2942 & 2951 & -0.3 & 551.3 & 551.5 & $<-0.1$ \\
\hline \hline
\end{tabular}

1 Similar distortions would occur in quarterly analyses, where unusual weather in June and December would be partly reflected in the following quarterly billings. The electricity send-out statistics would be accurate and provide part of the basis for the adjustments to sectoral sales data.

2 Cost of service regulation, practiced in various forms by nearly all state and local regulatory agencies, will result in continuing declines in the real price of electricity, even if fuel prices rise as projected. However, if general inflation should ensue, such higher rates of return that might be allowed by the commissions, plus inflation in fuel, labor, and other variable costs, might cause electricity prices to more nearly keep pace with other prices in general. 
Table 5. Analysis of Variations in U.S. Electricity Sales on a Year-to-Year Basis, 1986 to 1991

\begin{tabular}{||c||c|c|c||c|c|c|c||}
\hline \multicolumn{1}{|c||}{} & \multicolumn{2}{c||}{ Total National Sales (billion kWh) } & \multicolumn{3}{c||}{ Composition of Percent Change } \\
\cline { 2 - 9 } & Actual & $\begin{array}{c}\text { Change } \\
\text { from Prior } \\
\text { Year }\end{array}$ & $\begin{array}{c}\text { Percent } \\
\text { Change }\end{array}$ & $\begin{array}{c}\text { Weather } \\
\text { Effect }\end{array}$ & $\begin{array}{c}\text { Income } \\
\text { Effect }\end{array}$ & $\begin{array}{c}\text { Price } \\
\text { Effect }\end{array}$ & $\begin{array}{c}\text { Other } \\
\text { Effects }\end{array}$ \\
\hline \hline 1986 & 2355 & 49 & 2.1 & 0.16 & 2.07 & 0.95 & -1.06 \\
\hline 1987 & 2435 & 81 & 3.4 & 0.31 & 2.20 & 1.53 & -0.61 \\
\hline 1988 & 2554 & 119 & 4.9 & 0.94 & 2.80 & 1.39 & -0.26 \\
\hline 1989 & 2621 & 67 & 2.6 & -1.36 & 1.77 & 0.73 & 1.48 \\
\hline 1990 & 2669 & 48 & 1.8 & -0.07 & 0.70 & 0.69 & 0.50 \\
\hline $1991 \mathrm{P}$ & 2716 & 48 & 1.8 & 1.71 & -0.51 & 0.18 & 0.44 \\
\hline \hline
\end{tabular}

Source: Edison Electric Institute, 1992.

\section{Outlook for Electricity Demand}

As noted in Table 2, most of the cited forecasts of electricity demand project growth of 2 percent per year or slightly less over the next two decades, a drastically lower rate of growth than the 5 percent average rate experienced from 1960 to $1990 .^{3}$. The radical reduction in the growth rate of electric power demand began in the mid-1970s when the first OPEC crisis led to many actions by government, industry, and consumers to reduce energy demand. The sharp increases in oil and other fuel prices in the mid-1970s and again between 1979 and 1981 might suggest that higher electricity prices might have accounted for much of the slowdown in the growth of electricity demand. This is not the case. Electricity prices showed little increase from the 1970 levels and are still well below the 1960 levels in real terms, as shown in Figure 2.

The price data do not explain the radical reduction in the growth rates of the two fastest growing sectors-residential and commercial-and are inadequate to explain the industrial sector's response. In fact, the much greater relative price increases of natural gas, fuel oils, and coal should have, if other factors were equal, caused an increase in industrial demand for electricity, rather than the decrease that occurred. Table 4 illustrates the dramatic change in the growth patterns of electricity sales. The growth rate projected for GNP, lower than the average achieved in recent decades, would explain only a small reduction in the growth rate of demand.

It appears that better consumer information may have made a significant change in consumers' conservation behavior. Time-of-day rates, with differing levels of demand charges for peak and offpeak times and seasons, have allowed consumers to better evaluate ways of reducing costs of electric service. Information on appliance and equipment efficiency is improved and now readily available. Minimum performance standards now apply to many major electrical (and gas) residential appliances; more stringent standards for many of the appliances will become effective within a few years. Actions such as the elimination of common metering for apartment projects have given consumers incentives to conserve energy; whereas previously the incentives were the opposite. Some utilities have found

\footnotetext{
${ }^{3}$ National Economic Research Associates, Inc., a consulting firm having many gas and electric utilities among its clients, projects a higher growth rate of electric power sales over the next 15 years-about 3 percent per year (National Economic Research Associates, Inc. 1991).
} 


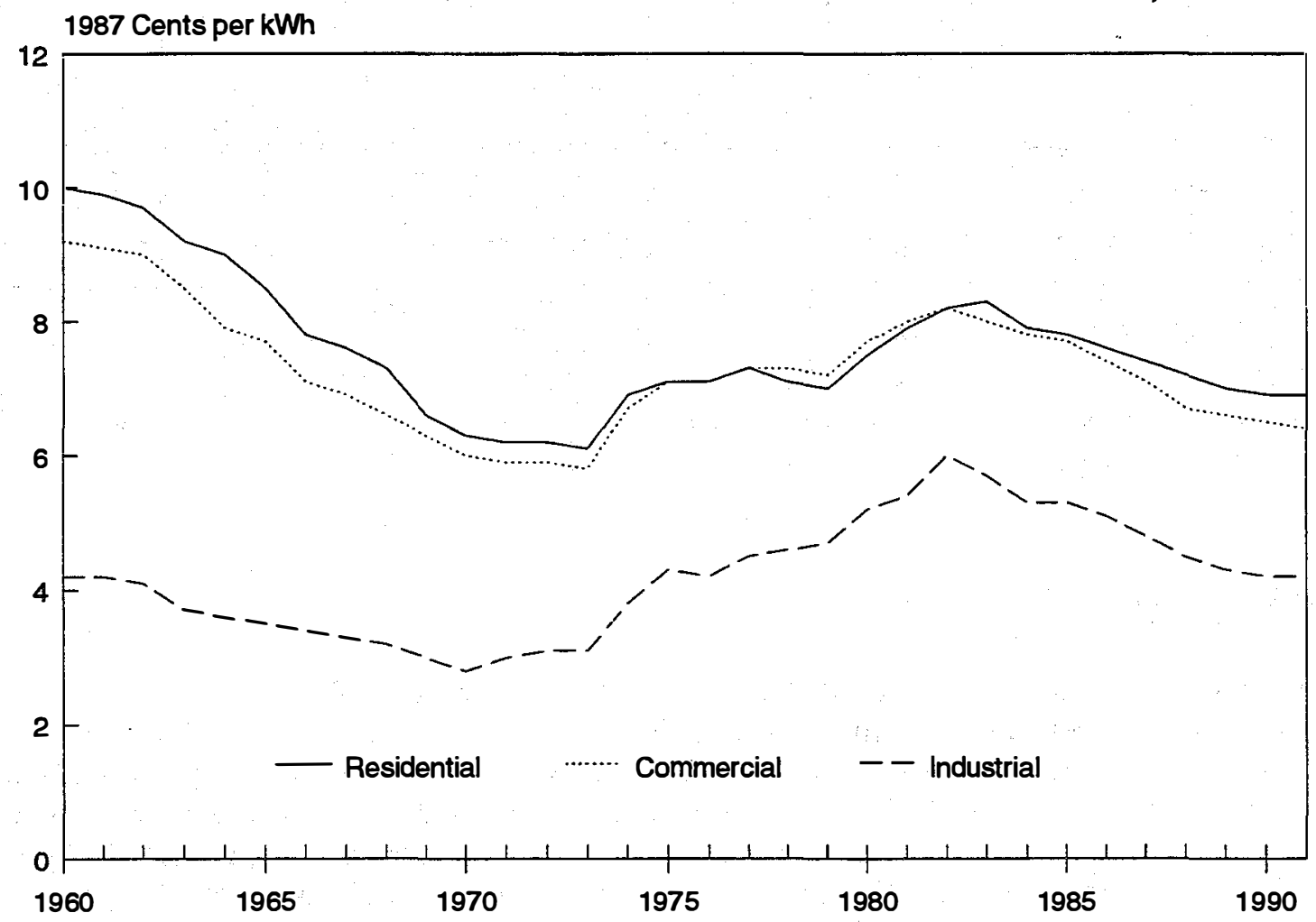

Source: EIA Annual Energy Review 1991

Figure 2. Trends in the real price of electricity by demand sector

individual metering of apartments to cut consumption by half after consumers receive their first separate bill. ${ }^{4}$ In addition, after years of declining costs, the rapid increase in rates due to inflation in the late 1970s, plus some real cost increases caused by rising fuel, new capacity, and interest costs, made residential consumers, in particular, more aware of electric service costs. The budgetary impact of unplanned increases in nondiscretionary household costs constrained other spending, forcing many families, particularly those in colder regions who used electric resistance heat, to make major adjustments.

The higher interest rates that have prevailed since 1970 made both residential and business consumers less willing to invest in conservation, particularly homeowners who are typically unsure of their long-

\footnotetext{
4 Houston Lighting \& Power Company (HL\&P) found that kilowatt-hour billings for aparment projects that were converted from a single master meter, with the bill paid by the owner and the cost rolled into rents, to individual meters, with the tenant paying, dropped an average of 50 percent after the first bills were received by the tenants. Personal communication-D. V. Hudson with Olin Seago, Rates and Economics Department, HL\&P, about 1980.
} 
Table 6. Historical Growth of Electricity Sales by Sector

\begin{tabular}{||l||c|c|c|c||}
\hline \multirow{2}{*}{ Electricity Sales by Sector } & \multicolumn{4}{|c||}{ Annual Rate of Growth (\%) } \\
\cline { 2 - 5 } & $1950-60$ & $1960-70$ & $1970-80$ & $1980-90$ \\
\hline \hline Residential & 10.81 & 8.77 & 4.40 & 2.61 \\
\hline Commercial & 9.89 & 8.89 & 4.74 & 4.48 \\
\hline \hline Industrial & 8.34 & 5.83 & 3.62 & 1.29 \\
\hline \hline Total & 8.99 & 7.30 & 4.17 & 2.58 \\
\hline \hline Gross National Product (\$1982) & 3.30 & 3.79 & 2.81 & 2.68 \\
\hline
\end{tabular}

Source: EIA Annual Energy Review 1990.

term residence in their current home-the average tenure in a house has been three years. ${ }^{5}$ Nonetheless, the efficiency gains appear to have been large. Today's lower interest rates reflect lower expectations of future inflation and reflect the current recession. If future interest rates materialize at the lower levels currently forecast, the demand for higher initial cost but more efficient appliances and equipment would be stronger than otherwise. It is not possible to determine the influence this factor may have played in the forecasts reviewed here.

\section{Residential Demand}

Residential electricity demand is projected to grow at rates ranging between 1 and 2 percent per year between 1990 and 2010. (NERC provides no sectoral breakdown of its demand projections.) All the projections are substantially lower than the 2.6 percent rate of increase in the $1980 \mathrm{~s}$. The Gas Research Institute (GRI) projects a 1.3 percent rate of increase, including the effects of a significant increase in use of electric heat pumps in the Northeast and increasing saturation of the air conditioning market by central and room electric air conditioners. EIA projects a 1.2 percent annual rate of growth. The Edison Electric Institute forecasts only 1.0 percent per year growth, reflecting the effect of r appliance and efficiency standards, utility demand-side management programs (DSM), and a lower rate of household formation. In contrast, the NES Current Policy Case assumes a declining share of the home heating market for electricity and no increase in air conditioning saturation after 1990, yet assumes a 2.0 percent growth in residential electricity sales. The NES Strategy Scenario projection of growth in electricity sales in the residential market is 1.6 percent per year, taking into account additional conservation actions versus the base case, presumably with similar assumptions regarding the role of electric space heating and cooling. DRI's forecast calls for a 1.7 percent annual growth, a higher rate than its 1990/1991 projections; however, DRI provides no substantiation of the basis for its outlook in its regular publications nor does it explain changes in its outlook. The apparently contradictory assumptions made by major forecasting organizations may be, in part, the result of the

\footnotetext{
5 It is not apparent whether the succession of changes in the job market will increase the average length of residence in a house. Less job security may foster more rapid changes and relocations. On the other hand, the reduction of corporate staffs and other restructuring appears to be reducing the frequency of transfers. Individuals also appear less willing to accept transfers. If average tenure in a home does rise, the incentives for investment in conservation will become stronger; this, coupled with lower interest rates, may significantly reduce the barriers for consumer conservation actions.
} 
industry paying much more attention to supply and potential supply technologies than to demand. This point will be addressed in broader terms later. ${ }^{6}$

A portion of the reduction in the projected rate of growth of demand is related to the imposition of minimum energy efficiency standards for new residential heating, cooling, refrigeration, water-heating, and other appliances and equipment for both new installations and replacements. Because of the long life cycles of such equipment, the full impact will not be realized for another decade. (Care must be exercised in estimating the impact of standards; the baseline for comparison must reflect the fact that significant improvement in average efficiency would have occurred in the absence of mandatory minimum standards.) One study estimates that the standards will result in annual savings of nearly 1 quad of energy by 2015 (Brookhaven National Laboratory 1988, 2-30). The forecasts cited herein take into account the standards but do not separately estimate their impact.

Other than the EIA Annual Energy Outlook, the forecasts do not explicitly reflect the Energy Policy Act of 1992. GRI and EEI, however, note that their projections assume the equivalent actions for conservation, appliance standards, and efficiency improvements that are being encouraged and, in some instances, mandated by the Act. The impact may be to substitute mandated action for DSM activity projected by GRI and EEI. President Clinton's energy agenda, as outlined in A Vision for Change In America (Executive Office 1993, 36, 37), would further encourage conservation. The proposed Btu Tax, in whatever form it may be enacted, would discourage energy consumption relative to other consumer choices. If any tax imposed is based on Btus of input resources, electricity costs will rise relative to natural gas and oil for direct applications of electricity, such as resistance water heating. The relative competitive impact would be small for heat pumps and other applications of electricity where the efficiency of its form is better utilized.

It is difficult not to be concerned that the forecasts of residential electricity sales may be significantly low. No allowance appears to be made for potential new household uses of electricity. Policy actions that would tighten building standards, require greater minimum efficiencies of appliances, or foster more effective DSM programs may be needed if it is desirable not to exceed the forecast level of demand growth. Recent immigration statistics and an apparent increase in the birth rate suggest that the forecasts of growth in housing may be too low, which would place additional upward pressure on residential electricity demand. The Census Bureau's Office of Projections is now recommending that its high immigration, high fertility case (Series 18 ) be used by government agencies (and others) as the basis for population projections.

\section{Commercial Demand}

Commercial demand was the fastest growing segment of electricity consumption over the past three decades. Commercial economic activity has expanded rapidly, in part because of the "unbundling" of some service activities that were formerly an integral part of the industrial sector. Commercial floor space is widely used as an index of activity in the sector, and energy utilization is often analyzed and forecasted on the basis of usage per square foot, despite the wide range of types of buildings and energy intensity. of use. The current recession and the effects of the 1986 tax act have had a major impact on commercial space utilization and construction activity and have resulted in a large surplus of office building and retail store space, two of the larger components of commercial energy demand. Nonetheless, the electricity use per gross square foot has increased. As the economy recovers from the recession, increased utilization of the existing commercial space, much of which is vacant, will tend to

\footnotetext{
6 It is important to note that the detailed documentation of a forecast such as GRI makes available (Gas Research Institute 1990) is valuable not only for evaluating the forecast, but for allowing the user to test the sensitivity of the outlook to key variables. It provides a base point and system for an independent projection of a sector or region, or for a comprehensive outlook.
} 
further increase electricity use per square foot. This may offset much or all of the continuing slowdown in office building and retail store construction. Nonetheless, all the forecasts project commercial demand to rise at substantially lower rates than in the past four decades, even after allowance for the lower growth rate projected for economic activity over the next two decades. Apparently the general assessment is that office and retail store building investment will (continue to) be less attractive investments than they were before the 1986 tax act, and the growth of commercial energy demand will be affected as greater efficiency in use of floor space will carry over into energy use.

The four more recent forecasts project commercial electric power demand to grow at a 1.5 to 2.0 percent rate, reflecting the increased attention being given to appliance, lighting, window, and building standards and the slowness at which the excess office and retail space is being utilized. GRI projects commercial sector demand for electricity from the utilities to rise 1.3 percent per year, with usage increasing in all types of buildings except restaurants, for which electricity demand is expected to decline slightly. No increase in electric space cooling (heat pumps and air conditioners) penetration in the commercial sector is assumed by GRI. GRI expects electricity from cogeneration to supply 6 percent of commercial electricity demand by 2010 versus 2 percent in $1990 .^{7}$ The NES cases assume continued increases in electric-powered space cooling. Apparently this assumption is the principal reason, in addition to the higher growth rate of GNP, that the NES projections are significantly higher than others.

Table 7. Forecast Growth Rates (\%) of Electricity Demand by Sector, 1990 to 2010

\begin{tabular}{||l||c|c|c|c||}
\hline & Residential & Commercial & Industrial & Total \\
\hline \hline EIA 1993 Annual Energy Outlook & 1.21 & 1.54 & $2.07^{\mathrm{a}}$ & 1.64 \\
\hline \hline DRI Fall-Winter 1992-1993 Outlook & 1.86 & 1.60 & 1.94 & 1.81 \\
\hline $\mid$ GRI 1993 Outlook & 1.33 & 1.52 & 1.63 & 1.52 \\
\hline $\mid$ EEl 1992 Electricity Futures & 0.99 & 1.83 & 3.43 & 1.76 \\
\hline $\mid$ 1991/1992 NES Current Policy Base & 2.00 & 2.85 & 2.75 & 2.58 \\
\hline \hline $1991 / 1992$ NES Strategy Scenario & 1.55 & 2.73 & 2.16 & 2.00 \\
\hline \hline
\end{tabular}

a. Includes generation for own use (primarily industrial cogeneration).

b. $1992-2010$.

7 The economics of cogeneration in the commercial sector depends on the generally simultaneous need of the consumer for electricity and heat (and possibly shaft power). GRI projects the 2010 use of natural gas for cogeneration to procure the following outputs:

\begin{tabular}{clr} 
Input (tril. Btu) & \multicolumn{2}{c}{ Output (tril. Btu) } \\
\hline 696 & Electricity & 257 \\
& Cooling & 93 \\
& Water Heating & 105 \\
& Space Heating & 176 \\
& Total & 631
\end{tabular}

Delivery of the same amount of electricity from a central station to the commercial consumer, including distribution losses, would require virtually the same energy input at a modem combined cycle plant. The 374 trillion Btu used for cooling and heating services represent net energy savings. 
If the growth in commercial economic activity relative to GNP, as reflected in the NES projections of expansion of floor space, returns to rates comparable to those in the 1960-1990 period, commercial electricity demand could grow about 0.5 to 1.0 percent per year faster because of that factor alone.

\section{Industrial Demand}

The growth rate of industrial demand has been slowing down relative to other sectors for several decades. More than two-thirds of industrial use of electricity is for machine drive. One-third of the balance (11 percent of the total) is used for direct heat applications; the balance is used for lighting, space conditioning, electrical processes, and other electric service. The heavy emphasis in the Energy Policy Act of 1992 on improving efficiency of industrial motors reflects the importance of this application of electricity, particularly in the industrial sector.

None of the forecasters provide much detail regarding how their forecasts were generated or what specific assumptions they made about growth in particular sectors. The reduction in the amount of material used per unit of manufacturing (and construction) output is clearly a major factor, both by reducing the amount of electric energy used in producing materials and by reducing the use of electricity in machining, forming, assembling, and transporting products within the plant. EEI notes that the shift of manufacturing from materials production to less energy-intensive product output is a major factor slowing the growth of industrial electric power demand. Further study of the industrial sector demand outlook appears warranted, particularly in view of the significant, but uncertain, potential for expanded cogeneration.

\section{NERC Forecasting Performance}

After reviewing the forecasts made by NERC respondents and the "outside" agencies, it was found that a significant potential appears to exist for all the forecasts to be significantly understating the forthcoming demand for electricity supplied by utilities. Two factors are key to this potential. First, most of the forecasts appear to assume more conservation and DSM actions than appear to be occurring. Thus, if there are few intensified policy actions by the federal, state, and local governments, supported by appropriate actions on the part of the relevant regulatory agencies and the utilities themselves, demand may grow at a significantly faster pace than projected.

The second factor is the forecasting behavior of the utilities responding to the NERC surveys. Since 1986, demand has grown 3 percent per year despite annual updates of forecasts for about 2 percent annual growth. Utilities continue to project 2 percent growth for the next decade. In the current regulatory environment, many utilities have strong incentives to minimize future capacity commitments, whether owned or contracted to nonutility generators (NUGs) (Applied Economic Research 1990). The adjustments tend to be merely the increasing of forecasts by the amount of the near-term "miss," some of which were due to extreme weather conditions. If the near-term outlook for demand growth is really closer to the 3 percent recent history than the 2 percent projection, substantially more capacity will be needed by 2000 than is now projected.

Presumably, if such may be true for the 1990s, today's forecasts for the early 2000s would also be low. Some of the potential shortfall may be supplied by increased cogeneration or self-generation, but there are potential problems in these areas also. The current recession, accompanied as it has been by mild weather, brought demand more in line with forecasts; as the recovery occurs, the degree of rebound of electricity demand growth will warrant watching. EEI's estimate that the effects of economic growth and price would have resulted in a 2.5 percent growth of demand in 1992, were it not for mild weather, suggests strongly that underforecasting of demand continues. 


\section{Evolution of New Markets}

None of the forecasts specifically address the outlook for new markets for electricity. New uses are largely omitted from consideration of "bottoms-up" forecasts, such as GRI's, in which only minor innovative new appliance demands may be incorporated. "Top-down" econometric projections would be more likely to include an element of new applications. However, such projections have been biased, in most instances, by the forecasters' conviction that the economy would continue to become more energy-, and thus, electricity-efficient, with electricity demand growing much slower than GDP, in contrast to historical experience.

None of the forecasts reviewed here discuss the implications of the development of an electric automobile market. If all light duty vehicles were to be replaced by battery-powered vehicles by 2030 , the demand for electricity would increase by more than 20 percent, or about 1.5 trillion $\mathrm{kWh}$, excluding the impact on electricity demand of battery manufacturing. The regional impact might be greater, particularly in California. Projected base-load generating capacity would be inadequate to meet demand during expected overnight recharging periods. However, the additional base load capacity required would reduce the mid-range and peaking capacity otherwise needed to meet daytime loads. In addition, the much higher load factor operation of the utilities would make the traditional 20 percent reserve margin inadequate to cope with routine maintenance, unscheduled maintenance, transmission/distribution failures, and abnormal weather demands. The larger proportion of base load capacity, typically coal or nuclear plants, having lower annual average availability than peaking units, is an obvious indicator of the need for increased reserve margins if battery-powered autos become the major portion of the fleet. ${ }^{8}$ Battery-charging rates would have to include a significant capacity component.

\section{Emergence of Cogeneration and Self-Generation}

Traditional forecasts of electricity demand, which usually project kilowatt-hour consumption, include only the electricity supplied by electric utilities. ${ }^{9}$ In the past, there was little interest in measuring the demand met by self-generators, whether or not cogenerated, because the amount was small and the interconnections of customers' generating facilities with the utilities encompassed only a portion of that supply. Following the changes in the regulatory environment that made cogeneration and selfgeneration more attractive, ${ }^{10}$ the market for such activity has grown rapidly. The time-of-day rates, imposed as part of the reform, made cogeneration more attractive in instances in which the units would be reducing the customer's peak demand, such as in air conditioning applications or continuous

8 Although the average load factor, including weekend slack periods of demand, might appear to provide adequate maintenance time, such would not be the case. Coal and nuclear units require, and will continue to require, extended out-of-service periods for scheduled major maintenance. In addition, off-peak capacity would have to be retained for pumping up pumped storage. Some renewable capacity would not be available at night (solar thermal, PV, and some wind); the same would be true for those hydro projects that have limited water availability and use that availability during daily peak hours.

${ }^{9}$ Forecasts of peak demand (in $\mathrm{kW}$ or MW) are usually made for utility service only because there is no measure of nonutility demand.

${ }^{10}$ Cogenerators could qualify for supply contracts to the utilities, often at advantageous rates. In addition, the utilities were generally forced to make more reasonable arrangements with other cogenerators and self-generators for the purchase of surplus power and the provision of backup supply. Previously, many utilities made cogeneration unattractive by such practices as refusing to buy power and pricing backup service at levels that made cogeneration uneconomical. 
process uses. Most of the attention appears to have been devoted by the forecasters to the cogeneration that is becoming a large part of the nonutility supply to the utilities.

The data indicate that self-generated power is becoming a significant portion of total demand. The self-generation and cogeneration supply now forecast for 2010 is nearly double that forecasted in 1991 for 2010. DRI and GRI believe that they have accounted for all of the power produced by selfgenerators, including cogenerators, (or nonutility generators [NUGs]) that are connected to utility systems. Similarly, EIA includes in its demand data the own-use power of NUGs. NERC projects NUG capacity available to utilities will rise from $19 \mathrm{GW}$ in 1992 to $43 \mathrm{GW}$ in 2001, or 5.5 percent of system capability (NERC 1992a, 16). The 1992 NERC outlook is nearly 25 percent higher than its 1990 projections. If there are additional self-generators of any size, they are probably mining, forest products, food processing, or other plants located in remote areas where the cost of utility connection and supply would be high. ${ }^{11}$ None of the forecasts reviewed here attempt to measure these markets, although EIA includes these markets in industrial energy demand estimates of the fuels (commercial and renewable) used to generate such power.

Until this year, GRI had the largest projection of self-generation supply. GRI has for several years been studying the cogeneration market, because it is a significant potential market for natural gas. The advent of the Public Utilities Regulatory Policies Act (PURPA), independent power producers (IPPs), and qualified cogeneration facilities, etc., has intensified the gas industry's interest. The modular character of gas turbines, whether or not used in a combined cycle mode, makes them nearly ideal for a wide range of cogeneration applications. ${ }^{12}$

Table 8. Cogeneration and Self-Generation Supply for Utility Sales and Producers' Own Use (billion kWh)

\begin{tabular}{||l||c|c|c||c|c|c|c|c|c||}
\hline \multirow{2}{*}{ Forecast } & \multicolumn{3}{|c|}{1990} & \multicolumn{3}{c|}{2000} & \multicolumn{3}{c|}{2010} \\
\cline { 2 - 11 } & Total & $\begin{array}{l}\text { Own } \\
\text { Use }\end{array}$ & $\begin{array}{l}\text { Utility } \\
\text { Supply }\end{array}$ & Total & $\begin{array}{l}\text { Own } \\
\text { Use }\end{array}$ & $\begin{array}{l}\text { Utility } \\
\text { Supply }\end{array}$ & Total & $\begin{array}{l}\text { Own } \\
\text { Use }\end{array}$ & $\begin{array}{l}\text { Utility } \\
\text { Supply }\end{array}$ \\
\hline \hline $\begin{array}{l}\text { ElA 1993 Annual Energy } \\
\text { Outlook }\end{array}$ & 218 & 111 & 106 & 386 & 171 & 215 & 590 & 182 & 408 \\
\hline $\begin{array}{l}\text { DRI Fall-Winter 1992- } \\
\text { 1993 Energy Outlook }\end{array}$ & 229 & 137 & 92 & 489 & 178 & 312 & 888 & 200 & 688 \\
\hline $\begin{array}{l}\text { GRI 1993 Energy } \\
\text { Outlook }\end{array}$ & 193 & 89 & 104 & 387 & 164 & 223 & 622 & 194 & 428 \\
\hline \hline
\end{tabular}

a. Includes independent power producers.

Note: Edison Electric Institute reports that in 1989, nonutility producers generated 201 billion kWh and delivered 94 billion $\mathrm{kWh}$ to the utilities; the balance was for their own use (and some transmission losses).

\footnotetext{
${ }^{11}$ Waste materials may also be available for use as fuel in many cases.

12 General Electric, for example, makes a 150-MW single shaft combined cycle unit (the STAG7 and 9 series), whereas Garrett makes packaged small turbines that generate electricity and provide shaft power for hydraulic and compressor units for aircraft when the main engines are shut down. A wide range of intermediate-sized turbines are available, which have varying degrees of flexible heat, shaft power, and electricity output. Gas turbines have been designed to be fueled by natural gas, petroleum (distillate, LPG, fuel oil, naphtha, and crude), by-product gases (steel, petroleum refining, chemicals, etc.), and gasified coal, wood, and waste materials.
} 
Moreover, if fuel cell technology research, development, and demonstration (RD\&D) achieves the sponsors' goals, the market for distributed electric power generation would multiply rapidly. The automotive fuel cell RD\&D needs to achieve costs equal to conventional internal combustion engine power systems to be competitive; if such is accomplished, as some auto industry analysts predict, the resulting system cost of about $\$ 100$ per kilowatt would make such fuel cells almost overwhelmingly competitive with utility systems as a distributed source of electricity for residential and commercial consumers, as well as for industry. Utilization of by-product heat might also be feasible. (Fuel cells would also be a major option considered by the utilities in their planning for additional capacity, potentially reducing the need for new central stations.) Natural gas would be the most likely energy supply for such fuel cells. Substantial progress is needed in both fuel cell and reforming (hydrogen supply) technology. Also, if RD\&D of PV, wind, and solar thermal generation technologies meet the cost goals of these technologies, they will be competitive in distributed end-user markets, on- or offgrid, as well as for utility system central station applications.

The development of the self-generation market will be difficult to track and forecast without greater data availability. DRI contended, in 1991, that most of the larger, more attractive cogeneration projects were identified and implemented, but doubled its forecast a year later. The smaller applications may be slower to develop, in part because potential users are frequently apprehensive about undertaking the management of complex systems having technologies unrelated to other activities at the establishment. Such markets may not develop fully until qualified service organizations, such as the local electric or gas utility, undertake the provision of needed operational and maintenance services. ${ }^{13}$

\section{Supply Outlook}

In the past, demand was usually considered the key uncertain factor in electricity market and supply analyses; supply could be counted on to be available as planned. Today the uncertainties regarding supply are probably greater than the uncertainties regarding demand. The planning process appears to have recognized that as a fact. The industry's supply/demand projections all give substantially more space and, apparently, effort to the analysis of supply options, probabilities of projects being approved/permitted/completed, and reliability of generation and transmission facilities than to the analysis of demand. Perhaps the greater ability to analyze statistically the supply technologies and their applications contributes to this effort. Some of the analyses, such as the Applied Energy Systems-Utility Data Institute (UDI) study, contend that there will be a supply shortage in the coming decade, based on the current plans (Applied Economic Research 1990, 19). Such reports do not correctly reflect the way in which the supply planning process operates. If demand continues to exceed expectations, the utilities will expand their plans for capacity additions. As the reliability of IPPs and cogenerators is demonstrated, -whether favorable or not, the utilities (with approval of their commissions) will respond with appropriate mixes of types and ownership of capacity. Clearly, the bulk of capacity added in the late 1990 s and early 2000 s will not be base load coal or nuclear plants. Actual shortages of capacity are likely only in circumstances in which local environmental or regulatory factors prevent the orderly addition of capacity.

The uncertainties of supply may exacerbate the problems that would arise if demand growth proves significantly stronger than now projected. The 1991 amendment to the Clean Air Act is expected to increase the costs of electricity by its imposition of tighter emission standards. This is not news. However, the costs, site problems, and regulatory and local approvals needed for coal plant

\footnotetext{
13 The utilities ultimately may also own the cogeneration plants, either as part of their rate bases or as part of nonutility services. Such services are now provided by utilities outside their own service areas, such as by VEPCO's Dominion Energy, for larger installations.
} 
modifications may result in greater down-rating and retirements of plants than are generally expected. More new replacement capacity may be needed than is now projected; this is likely a one-way uncertainty-much more rather than less.

The long-term reliability of cogenerators and IPPs is yet to be demonstrated. Cogenerators, particularly those related to a cyclical industry, may not be operating at expected levels at times of future peak demands; some may even close because of changes in their industrial climate. ${ }^{14}$

The utilities are clearly banking on the modularity, low capital costs, currently low fuel costs, and adaptability of natural gas combustion turbine and combined cycle plants to cope with the upside demand uncertainties that may lie ahead. If natural gas prices rise, generally expected to occur eventually, making base load operation of combined cycle plants less attractive than new coal (or nuclear) plants, then the gas units could be shifted to intermediate or peaking service, with little or no penalty compared with alternatives. In the meantime, the favorable environmental atributes of natural gas provide a significant benefit. The alternative of renewable energy technologies is not expected to be economic except in relatively few localized regional circumstances in which exceptional highly productive renewable resources are available, such as wind sites, geothermal deposits, or untapped and environmentally acceptable hydro resources. ${ }^{15}$

\section{New Capacity under Construction}

A major uncertainty of supply relates to the status of planned or projected capacity expansion projects. Two aspects of this issue are important. First, is there adequate base load capacity existing, under construction, or planned that can meet economically the base load demand under a reasonable range of demand scenarios? Second, do the utilities have sufficient flexibility in supply planning and implementation to meet either higher or lower than projected capacity needs? Many statistical studies of the adequacy of supply planning focus on the possibilities that planned capacity may be inadequate if, 10 or 20 years later, demand proves to be greater or some supply sources prove to be less than projected, and no action had been taken in the interim by the utilities to adjust their supply plans. The 1990 UDI study is an example (Applied Economic Research 1990). ${ }^{16}$

At the time the Swezey report (Swezey 1988) was prepared, the NERC supply projection for 1995 indicated that 59 percent of the capacity needed in the coming decade was under construction; more than half of that under construction was nuclear and most of the balance was coal. At the time of reporting for the 1992 NERC reports, generally January 1, 1992, only 24 percent of the additional utility capacity needed by 2001 was under construction, $14.2 \mathrm{MW}$ of $59.8 \mathrm{MW}$ total planned capacity. Net additions of 19-GW capacity by NUGs is also planned, an 80 percent increase in such capacity in the decade 1991-2001. Consequently, very little traditional base load capacity will be added in the 1990s, even if demand should rise more rapidly than expected, because of the regulatory, environmental, and construction lead times involved for facilities not now under way. The portion of

\footnotetext{
14 There are a host of technical and operational matters that require coordination and cooperation among utilities and nonutility suppliers. Some degree of supply unreliability may arise if all these issues are not fully resolved. See North American Electric Reliability Council (1992c), Integrating Non-Utility Generators, Januany, 1992, NERC, Princeton, N.J.

15 The potential also exists for upgrading the efficiency of use of existing hydro resources in many locations where little or no additional environmental impact would be involved.

16 The study concludes that shortages in several regions are likely unless changes are made in plans. The important point that is not made, however, is that the utilities' planning processes are ongoing and are likely to respond, and that the critical issue is whether the utilities have passed or may pass the point of no return.
} 
energy supplied from coal and nuclear plants is thus projected to decline slightly, from 74 percent in 1990 to 71 percent in 2000. However, the average capacity utilization factors for coal and nuclear are projected to rise from 60 percent and 68 percent, respectively, in 1990, to 68 percent and 73 percent, respectively, in $2000 .{ }^{17}$ Thus, the base load capacity may be strained, particularly if demand exceeds expectations and/or if environmental regulations, particularly those pursuant to the amendments to the Clean Air Act, prove to limit capacity to a greater degree than included in the NERC projections.

Most of the new capacity to be added by the utilities between 1990 and 2000 is planned to be naturalgas-fueled combustion turbines and combined cycle plants, according to NERC reports (NERC, 1992b). Such plants have much shorter lead times for construction than do coal or nuclear plants. If necessary, significantly more such plants could be built than are now planned. The most recent outlooks for natural gas prices suggest that the cost would not be extremely high to provide a significant portion of projected midrange and even base load power demand from natural-gas-fueled combined cycle plants. Thus there does not now appear to be a significant immediate penalty likely to be attached to opting for the minimal base load commitment. After 2000, if demand proves stronger than forecast and economic nuclear or coal plants can be placed in service, any excess natural gas base load plants can be shifted to peaking and lower midrange load factor service.

Only one-fourth of planned NUGs' capacity was under construction on January 1, 1991 (three-quarters of that was scheduled for 1991 completion) (NERC, 1991b). (Similar data were not provided in the 1992 report.) About 20 percent of 1991 planned completions, 80 percent of 1992 planned completions, and virtually all of plants expected on line between 1993 and 2000 were not under construction. The utilities responding to the NERC data requests project NUG capacity based on the utilities own assessments of the ongoing status of the NUGs, and not on the basis of the capacity announced or planned by the IPP industry. (For example, the ERCOT ${ }^{18}$ regional projection assumes that during the coming decade, contracts will expire and will not be renewed for nearly $2 \mathrm{GW}$ of NUG capacity.) Thus, the utilities may be called on to utilize their own resources to provide a portion of the planned NUG capacity.

\section{Impact of Efforts to Improve Load Factors}

The NERC projections show that the national average system annual load factor is expected to improve from 60.4 percent in 1990 to 61.6 percent in 2000, a small improvement that is possibly misleading because the 1990 summer peak was influenced by abnormally high temperatures in some areas. The NERC projections include the amount of utility-controlled demand management and interruptible contracts, illustrating the utilities' ability to reduce capacity requirements in unusual conditions, which is projected to reach $26.3 \mathrm{GW}$ in 2001 . This capability may be overstated, however. Unlike generation capacity, which if idle on one system can be used to support another, DSM capacity is largely restricted by contract to use on the host utility's system; it might not be usable in instances in which needs were not general in a region. Also, many industrial consumers who have entered into load management or interruptible contracts based on past experience of few (or no) instances of interruption, may find that the more frequent exercise of the option by the utility is unacceptable. The costs of plant shutdowns may exceed the value of the savings from lower electricity rates. This appears to be happening to some degree (Applied Economic Research 1990, 42). (Mandatory

\footnotetext{
17 Actual net electricity production for load divided by total capacity x 8760 hours. Unutilized potential capacity is not included.

${ }^{18}$ Electric Reliability Council of Texas.
} 
interruptible contracts could result in some industries relocating or locating all expansions in areas without such restrictions.)

\section{Impact of Uncertainties of Demand and Supply}

The likelihood appears significantly greater that demand may be larger than that currently projected in 2000 and 2010, rather than lower. If demand does exceed the forecast, significant additional capacity would have to be provided by the utilities. Since the utilities do not now have all their projected capacity needs fully planned, with sites and regulatory approvals obtained, pressures to add modular units, such as gas turbines, natural gas combined cycle plants, or some renewable energy units (e.g. wind or PV), will be much greater in the first decade than now contemplated. For example, if demand were to grow at a 1 percent per year faster rate than projected and all of the incremental demand versus the current 2 percent average forecast were supplied by natural gas-primarily combined cycle plants plus some combustion turbines-the added natural gas demand would be about 3 Tcf $^{19}$ by 2000 , or nearly a 15 percent addition to the total demand for natural gas for all uses, not just electric power generation. (Neither substantial coal nor nuclear plant capacity could be added by 2000 unless the planning and permitting process begins within a year or two.) Such an increase in demand would require expansion of pipeline and distribution system capacity as well as increased exploration, development, and production. Prices for natural gas would likely be significantly higher. The opportunities for competitive modular technologies, such as many renewable technologies, would be enhanced significantly.

If the growth in electricity demand is stronger than projected between 2000 and 2010 , and coal and nuclear capacity cannot be added to fill the gap, the amount of new natural gas or renewable capacity needed would be correspondingly greater (assuming that utilities would not build much oil-only capacity). Similarly, if currently planned coal and nuclear capacity does not materialize, due to derating of existing plants or curtailments or delays in new construction, additional natural gas or renewable capacity may be needed than is now projected, some possibly before 2000 .

If demand proves to be less than forecast, the utilities should be able to cancel or defer new capacity additions with little difficulty. No general surplus of base load capacity is likely to occur (no attempt was made herein to analyze the plans of individual utilities; even those that might have on-system surpluses of base load capacity would be likely to have ample opportunities to sell low-cost off-peak power to other utilities). Costs would be lower; the use of natural gas and petroleum fuels would be lower than otherwise, possibly leading to lower prices (or smaller increases) for those fuels.

No capacity shortage is envisioned as the result of variations in demand, even in the most extreme potential case, because utilities have the ability to adjust plans and construction schedules as needed, and the technologies and resources that would be required are available. Prolonged delays in regulatory or environmental approvals of generating plants, transmission lines, or natural gas pipelines could result in some regional problems; no attempt was made in this study to identify such possibilities.

191 cubic foot $=2.831685 \times 10^{-2}$ cubic meter. 


\section{References}

Applied Economic Research Co., Inc., 1990, The Adequacy of U.S. Electric Supply through the Year 2000, Issues and Impacts for the Nineties, Utility Data Institute, Inc., Washington, D.C.

Brookhaven National Laboratory, July 1988, Analysis and Technology Transfer, Annual Report - 1987, Buildings and Community Systems, Brookhaven National Laboratory, Upton, N.Y.

Edison Electric Institute, Electricity Futures: America's Economic Imperative, 1992, Strategic Planning Department, Edison Electric Institute, Washington, D.C.

Edison Electric Institute, 1992, Strategic Planning Department, unpublished work sheets, Edison Electric Institute, Washington, D.C.

Energy Information Administration, 1990, EIA Annual Energy Review 1990, DOE/EIA-0383(90), Energy Information Administration, Department of Energy, Washington, D.C.

Executive Office of the President of the United States, 1993, A Vision for Change in America, February 17.

Gas Research Institute, December 1990, Baseline Projection Data Book, GRI Baseline Projection of U.S. Energy Supply and Demand to 2010, 1991 Edition, Gas Research Institute, Washington, D.C.

Gas Research Institute, December 1991, Baseline Projection Data Book, GRI Baseline Projection of U.S. Energy Supply and Demand to 2010, 1992 Edition, Gas Research Institute, Washington, D.C.

Gas Research Institute, December 1992, Baseline Projection Data Book, GRI Baseline Projection of U.S. Energy Supply and Demand to 2010, 1993 Edition, Gas Research Institute, Washington, D.C.

Holt, T.A., January 1993, Overveiw of the Electric Vehicle and the Electric Utility, Analytic Studies Division, National Renewable Energy Laboratory, Golden, Colo., Final Draft.

Leasburg, R.H., 1989, "Power Generation: Who Will Do It and How?" Natural Gas \& Electric Power, Partners for the 1990s?, Cambridge Energy Forum, Cambridge Energy Research Associates, Inc., Cambridge, Mass.

National Economic Research Associates, Inc., December 23, 1991, NERA Energy Outlook, National Economic Research Associates, Inc., White Plains, N.Y.

North American Electric Reliability Council (NERC), 1987, 1987 Electricity Supply \& Demand, NERC, Princeton, N.J.

North American Electric Reliability Council (NERC), 1988, 1988 Electricity Supply \& Demand, NERC, Princeton, N.J.

North American Electric Reliability Council (NERC), 1989, 1989 Electricity Supply \& Demand, NERC, Princeton, N.J.

North American Electric Reliability Council (NERC), 1990, 1990 Electricity Supply \& Demand, NERC, Princeton, N.J. 
North American Electric Reliability Council (NERC), 1991a, Reliability Assessment 1991-2000, NERC, Princeton, N.J.

North American Electric Reliability Council (NERC), 1991b, 1991 Electricity Supply \& Demand, NERC, Princeton, N.J.

North American Electric Reliability Council (NERC), 1992a, Reliability Assessment 1992-2001, NERC, Princeton, N.J.

North American Electric Reliability Council (NERC), 1992b, 1992 Electricity Supply \& Demand, NERC, Princeton, N.J.

North American Electric Reliability Council (NERC), 1992c, Integrating Non-Utility Generators, January, 1992, NERC, Princeton, N.J.

Oatman, E. N., and T. L. Talbert, June 1989, Assessing Supply and Demand Uncertainties, Report P-6369, Electric Power Research Institute, Palo Alto, Calif.

Swezey, Blair G., March 1988, Review and Analysis of Electricity Supply Market Projections, SERIMR360-3322, Solar Energy Research Institute.

U.S. Department of Energy, 1991, Integrated Analysis Supporting The National Energy Strategy: Methodology, Assumptions And Results, National Energy Strategy, Technical Annex 2, DOE/S0086P, U.S. Department of Energy, Washington, D.C. 


\section{Bibliography}

Applied Economic Research Co., Inc., 1987, The Adequacy of U.S. Electricity Supply Through the Year 2000, Issues and Impacts for the Nineties, Utility Data Institute, Inc., Washington, D.C.

Bakarat \& Chamberlin, Inc., 1990, Proceedings: Demand-Side Management Incentive Regulation, EPRI CE-6840, Electric Power Research Institute, Palo Alto, Calif.

Bakarat \& Chamberlin, Inc., 1990, Efficient Electricity Use: Estimates of Maximum Energy Savings, EPRI CU-6746, Electric Power Research Institute, Palo Alto, Calif.

Bloomster, C. H., and E. T. Merrill, 1987, Long-Term Need for New Generating Capacity, PNL-6193, Pacific Northwest Laboratory, Richland, Wash.

Brookhaven National Laboratory, May 1989, Analysis and Technology Transfer, Annual Report - 1988, Buildings and Community Systems, Brookhaven National Laboratory, Upton, N.Y.

Carlsmith, R.B., W.U. Chandler, J.E. McMahon, D.J. Santini, 1990, Energy Efficiency: How Far Can We Go?, Oak Ridge National Laboratory, Oak Ridge, Tenn.

Clarke, James, Feb. 14, 1992, "Utilities In For A Rude Awakening, Wams Gale," The Energy Daily, p. 3.

President Clinton's State of the Union Address to Congress, February 18, 1993, Bureau of National Affairs, Inc., Washington, D.C.

Congress of the United States, October 24, 1992, Energy Policy Act of 1992, Public Law 102-486, Government Printing Office, Washington, D.C.

Dreyfus, Daniel A., August 1991, GRI Baseline Projection of U.S. Energy Supply and Demand, 1992 Edition, Gas Research Institute, Washington, D.C.

DRIMcGraw-Hill, 1989, Energy Review, Electricity Outlook, Spring 1989, DRI/McGraw-Hill Division, Standard \& Poor's Corp., Lexington, Mass.

DRI/McGraw-Hill, 1990, Energy Review, Electricity Market Focus, Winter 1989-1990, DRI/McGraw- Hill Division, Standard \& Poor's Corp., Lexington, Mass.

DRI/McGraw-Hill, 1990, Energy Review, Electricity Market Focus, Spring 1990, DRI/McGraw-Hill Division, Standard \& Poor's Corp., Lexington, Mass.

DRIMcGraw-Hill, April 1991, Energy Review, Electricity Market Focus, Second Quarter 1991, DRI/McGraw-Hill Division, Standard \& Poor's Corp., Lexington, Mass.

DRIMcGraw-Hill, October 1991, Energy Review, Electricity Market Focus, Fourth Quarter 1991, DRI/McGraw-Hill Division, Standard \& Poor's Corp., Lexington, Mass.

DRIMcGraw-Hill, July 1991, Energy Review, Electricity Market Focus, Third Quarter 1991, DRI/McGraw-Hill Division, Standard \& Poor's Corp., Lexington, Mass.

DRI/McGraw-Hill, 1992, Energy Review, Fall-Winter 1992-1993, DRIMcGraw-Hill Division, Standard \& Poor's Corp., Lexington, Mass. 
Edison Electric Institute, Spring 1984, "What happened to the 40 Percent?," Electric Perspectives, Edison Electric Institute, Washington, D.C. pp. 28-31.

Edison Electric Institute, 1989, Electricity Futures: America's Economic Imperative, Edison Electric Institute, Washington, D.C.

Edison Electric Institute, 1989, Statistical Yearbook of the Electric Utility Industry/1988, Edison Electric Institute, Washington, D.C.

Edison Electric Institute, 1991, 1989 Capacity and Generation of Non-Utility Sources of Energy, Edison Electric Institute, Washington, D.C.

Energy Information Administration, 1991, Annual Outlook for U.S. Electric Power 1991, DOE/EIA0474(91), U.S. Department of Energy, Washington, D.C.

Energy Information Administration, 1983, Cogeneration: Regulation, Economics and Capacity; Volume 2: Economics and Capacity, DOE/EIA-0421, Vol. 2 of 2, U.S. Department of Energy, Washington, D.C.

Energy Information Administration, 1985, Analysis of Growth in Electricity Demand, 1980-1984, DOE/EIA-0476, U.S. Department of Energy, Washington, D.C.

Energy Information Administration, 1986, Energy Forecasts for 1985, DOE/EIA-0495, U.S. Department of Energy, Washington, D.C.

Energy Information Administration, 1987, Regional Projections of End-Use Energy Consumption and Price Through 2000, April 1987, SR/EAFD/87-07, U.S. Deparment of Energy, Washington, D.C.

Energy Information Administration, 1989, Estimates of Short-Term Petroleum Fuel Switching Capability, DOE/EIA-0526, U.S. Department of Energy, Washington, D.C.

Energy Information Administration, 1989, Regional Projections of End-Use Energy Consumption and Price Through 2000, April 1989, SR/EAFD/89-01, U.S. Department of Energy, Washington, D.C.

Energy Information Administration, 1990, An Analysis of Heating Fuel Market Behavior 1989-1990, SR/OG/90-01, U.S. Department of Energy, Washington, D.C.

Energy Information Administration, 1990, Manufacturing Energy Consumption Survey: Changes in Energy Efficiency, 1980-1985, DOE/EIA-0156(85), U.S. Department of Energy, Washington, D.C.

Energy Information Administration, 1991, Annual Energy Outlook 1991, DOE/EIA-0383(91), U.S. Department of Energy, Washington D.C.

Energy Information Administration, 1991, Annual Outlook for U.S. Electric Power 1991, Projections Through 2010, DOE/EIA-0474(91), U.S. Department of Energy, Washington D.C.

Energy Information Administration, 1991, Assumptions for the Annual Energy Outlook 1991, DOE/EIA0527(91), U.S. Department of Energy, Washington, D.C.

Energy Information Administration, 1993, Annual Energy Outlook 1993, DOE/EIA-0383(93), U.S. Department of Energy, Washington D.C. 
Energy Information Administration, 1993, Assumptions for the Annual Energy Outlook 1993, DOE/EIA0527(93), U.S. Department of Energy, Washington, D.C.

Energy Information Administration, 1993, Supplement to the Annual Energy Outlook 1993, DOE/EIA-0544(93), U.S. Department of Energy, Washington, D.C.

Eto, J., C. Blumstein, and M. Jaske, 1988, "Changing Needs in Electricity Demand Forecasting: A California Perspective," Planning and Forecasting, Volume 8, American Council for an Energy Efficient Economy, Washington, D.C., pp. 8.70-8.80.

Executive Office of the President of the United States, February 17, 1993, A Vision of Change for America, Executive Office of the President of the United States, Washington, D.C.

Gas Research Institute, December 1989, Baseline Projection Data Book, GRI Baseline Projection of U.S. Energy Supply and Demand to 2010, 1989 Edition, Gas Research Institute, Washington, D.C.

Government Accounting Office, 1990, Electricity Supply, Older Plants' Impact on Reliability and Air Quality, GAO/RCED-90-200, Government Accounting Office, Washington, D.C.

Gupta, P. C., A. Faruqui, and J. B. Wharton, 1987, "Structural Change in U.S. Manufacturing and Future Electricity Demand," Global Energy Interactions, The Riverdale Company, Inc., Riverdale, Md., pp. 75-90.

Hirst, E., 1990, "Balancing the Scales: Toward Parity in Electric Supply and Demand Data," The Electricity Journal, May, pp. 28-33.

Hirst, E., 1991, Possible Effects of Electric-Utility DSM Programs, 1990 to 2010, ORNL/CON-312, Oak Ridge National Laboratory, Oak Ridge, Tenn.

North American Electric Reliability Council (NERC), 1986, 1986 Electricity Supply \& Demand, NERC, Princeton, N.J.

North American Electric Reliability Council (NERC), 1987, 1987 Reliability Assessment, The Future of Bulk Electric System Reliability in North America, 1987-1996, NERC, Princeton, N.J.

North American Electric Reliability Council (NERC), 1988, 1988 Reliability Assessment, The Future of Bulk Electric System Reliability in North America, 1988-1997, NERC, Princeton, N.J.

North American Electric Reliability Council (NERC), 1989, 1989 Reliability Assessment, The Future of Bulk Electric System Reliability in North America, 1989-1998, NERC, Princeton, N.J.

North American Electric Reliability Council (NERC), 1990, 1990 Reliability Assessment, The Future of Bulk Electric System Reliability in North America, 1990-1999, NERC, Princeton, N.J.

North American Electric Reliability Council (NERC), 1991, 1991 Reliability Assessment, The Future of Bulk Electric System Reliability in North America, 1991-2000, NERC, Princeton, N.J.

Office of Policy Planning and Analysis, 1988, The Links Between Weather-Normalized Electric Demand and Economic Growth, DOE/PE-0083, U.S. Department of Energy, Washington, D.C. 
Parsons, B., B. Swezey, K. Porter, K. Sinclair, and T. Holt, March 1993, Near-term Demand and Marketside Analysis of Geothermal Electric Power, Analytic Studies Division, National Renewable Energy Laboratory, Golden, Colo., DOE Review Draft.

Resource Dynamics Corporation, 1990, Electrotechnology Reference Guide, Revision 1, EPRI EM-4527, Electric Power Research Institute, Palo Alto, Calif.

SFA Pacific Inc., 1990, Future Cogeneration Technologies, EPRI CU-6795, Electric Power Research Institute, Palo Alto, Calif.

Strategic Decisions Group, 1990, Assessing Supply and Demand Uncertainties, EPRI P-6369, Electric Power Research Institute, Palo Alto, Calif.

Swezey, Blair G., 1992, The Current Status of Renewable Electric Generation in the U.S.: Deployment, Economics, and Policies, NARUC-DOE Fourth National Integrated Resource Planning Conference, September 13-16, 1992, National Renewable Energy Laboratory, Golden, Colo.

The WEFA Group, 1991, Energy Analysis Quarterly, Winter 1991, WEFA Inc., Bala Cynwood, Pa.

U.S. Department of Energy, 1989, Staff Report, Electric Power Supply and Demand for the Contiguous United States 1988-1997, DOE/IE-0013, U.S. Department of Energy, Washington, D.C.

U.S. Department of Energy, 1990, Staff Report, Electric Power Supply and Demand for the Contiguous United States 1988-1997, DOE/IE-0018, U.S. Department of Energy, Washington, D.C.

U.S. Department of Energy, 1991, National Energy Strategy, Powerful Ideas for America, First Edition 1991/1992, U.S. Department of Energy, Washington, D.C.

Wetrogan, Signe I., 1990, Projections of the Population of States by Age, Sex, and Pace: 1989 to 2010, Current Population Reports, Series P-25, No. 1053, Bureau of the Census, U.S. Department of Commerce, Washington, D.C. 


\begin{tabular}{|c|c|c|c|}
\hline $\begin{array}{l}\text { Document Control } \\
\text { Page }\end{array}$ & $\begin{array}{l}\text { 1. NREL Report No. } \\
\text { NREL-TP-462-5049 }\end{array}$ & $\begin{array}{l}\text { 2. NTIS Accession No. } \\
\text { DE92016435 }\end{array}$ & 3. Recipient's Accession No. \\
\hline \multirow{2}{*}{\multicolumn{3}{|c|}{$\begin{array}{l}\text { 4. Title and Subtitle } \\
\text { Analysis of Recent Projections of Electric Power Demand }\end{array}$}} & $\begin{array}{l}\text { 5. Publication Date } \\
\text { August } 1993\end{array}$ \\
\hline & & & 6. \\
\hline \multicolumn{3}{|l|}{$\begin{array}{l}\text { 7. Author(s) } \\
\text { David V. Hudson }\end{array}$} & 8. Performing Organization Rept. No. \\
\hline \multirow{2}{*}{\multicolumn{3}{|c|}{$\begin{array}{l}\text { 9. Performing Organization Name and Address } \\
\text { National Renewable Energy Laboratory } \\
1617 \text { Cole Boulevard } \\
\text { Golden, Colorado } 80401-3393\end{array}$}} & $\begin{array}{l}\text { 10. Project/Task/Work Unit No. } \\
\text { AS } 815440\end{array}$ \\
\hline & & & $\begin{array}{l}\text { 11. Contract (C) or Grant (G) No. } \\
\text { (C) } \\
\text { (G) }\end{array}$ \\
\hline \multirow{2}{*}{\multicolumn{3}{|c|}{ 12. Sponsoring Organization Name and Address }} & $\begin{array}{l}\text { 13. Type of Report \& Period Covered } \\
\text { technical report }\end{array}$ \\
\hline & & & 14. \\
\hline \multicolumn{4}{|c|}{ 15. Supplementary Notes } \\
\hline \multicolumn{4}{|c|}{$\begin{array}{l}\text { 16. Abstract (Limit: } 200 \text { words) } \\
\text { This report reviews the changes and potential changes in the outlook for electric power demand since the } \\
\text { publication of Review and Analysis of Electricity Supply Market Projections (B. Swezey, SERIMR-360-3322, } \\
\text { National Renewable Energy Laboratory). Forecasts of the following organizations were reviewed: DOE/Energy } \\
\text { Information Administration, DOE/Policy Office, DRIMcGraw-Hill, North American Electric Reliability Council, } \\
\text { and Gas Research Institute. Supply uncertainty was briefly reviewed to place the uncertainties of the demand } \\
\text { outlook in perspective. And discussed were opportunities for modular technologies, such as renewable energy } \\
\text { technologies, to fill a potential gap in energy demand and supply. }\end{array}$} \\
\hline \multicolumn{4}{|c|}{$\begin{array}{l}\text { 17. Document Analysis } \\
\text { a. Descriptors } \\
\text { electric power demand; demand forecasts; electric power } \\
\text { b. Identifiers/Open-Ended Terms }\end{array}$} \\
\hline \multirow{2}{*}{\multicolumn{2}{|c|}{$\begin{array}{l}\text { 18. Availability Statement } \\
\text { National Technical Information Service } \\
\text { U.S. Department of Commerce } \\
\text { 5285 Port Royal Road } \\
\text { Springfield, VA } 22161\end{array}$}} & & $\begin{array}{l}\text { 19. No. of Pages } \\
38\end{array}$ \\
\hline & & & $\begin{array}{l}\text { 20. Price } \\
\text { A03 }\end{array}$ \\
\hline
\end{tabular}

Form No. 0069E (6-30-87) 